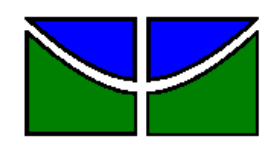

Universidade de Brasília

Faculdade de Economia, Administração e Contabilidade e Gestão de Políticas Públicas Departamento de Economia

Programa de Pós-Graduação em Economia

Mestrado Profissional em Economia

LUCIANA ALVES DE AZEVEDO

MENSURANDO E AVALIANDO A EFICIÊNCIA DOS GASTOS NOS CURSOS DE GRADUAÇÃO DA UnB

Brasília 


\section{MENSURANDO E AVALIANDO A EFICIÊNCIA DOS GASTOS NOS CURSOS DE GRADUAÇÃO DA UnB}

Dissertação apresentada ao Programa de PósGraduação em Economia da Faculdade de Economia, Administração, Contabilidade e Gestão de Políticas Públicas da Universidade de Brasília como requisito parcial para obtenção do título de Mestre em Economia. Área de concentração: Finanças Públicas.

Orientadora: Profa. Dra. Ana Carolina Pereira Zoghbi 
Azevedo, Luciana Alves de.

Mensurando e Avaliando a Eficiência dos Gastos nos Cursos de Graduação da UnB / Luciana Alves de Azevedo - 2015.

$74 \mathrm{f.}: 30 \mathrm{~cm}$.

Orientador: Ana Carolina Pereira Zoghbi.

Dissertação (Mestrado Profissional) - Universidade de Brasília, Faculdade de Economia, Administração, Contabilidade e Gestão de Políticas Públicas, Programa de Pós-Graduação em Economia, 2015.

1. Gastos. 2. Cursos da UnB. 3. Eficiência. 4. DEA. I. Zoghbi, Ana Carolina Pereira. II. Universidade de Brasília. Mestrado Profissional em Economia. III. Titulo. 


\section{MENSURANDO E AVALIANDO A EFICIÊNCIA DOS GASTOS NOS CURSOS DE GRADUAÇÃO DA UnB}

A Comissão Examinadora, abaixo identificada, aprova a Dissertação apresentada ao Programa de Pós-Graduação em Economia da Faculdade de Economia, Administração, Contabilidade e Gestão de Políticas Públicas da Universidade de Brasília como requisito parcial para obtenção do título de Mestre em Economia. Área de concentração: Finanças Públicas.

Profa. Dra. Ana Carolina Pereira Zoghbi - Orientadora

Departamento de Economia da UnB

Prof. Dr. Rafael Terra de Menezes - Membro Departamento de Economia da UnB

Profa. Dra. Milene Takasago - Suplente Departamento de Economia da UnB

Prof. Dr. Marcelo Driemeyer Wibert - Membro Departamento de Ciências Contábeis e Atuariais da UnB 
"Educar é impregnar de sentido o que fazemos a cada instante.

Paulo Freire 
Dedico aos meus amados pais Ademar e Marli e aos meus amigos de todo instante. 


\section{AGRADECIMENTOS}

À Deus, meu Pai eterno e Senhor, que me concedeu os dons da vida e da sabedoria. Sinto a Sua presença, o Seu amor e toda a Sua bondade constantemente, e afirmo, com toda certeza, que sem Ele eu nada teria conseguido. Louvo a Deus por mais esta conquista. Obrigada Senhor por tanto amor!!!!

À minha família, em especial, aos meus pais: Ademar e Marli. Também à minha sobrinha Anna Letícia; minha irmã Ana e meu cunhado Rogério, e a todos meus familiares pelas orações, incentivo e torcida.

À minha orientadora Profa. Dra. Ana Carolina Pereira Zoghbi, pela acolhida, apoio, carinho, compreensão e compartilhamento de seu vasto conhecimento.

Não posso deixar de agradecer a todos geniais professores doutores que em vários momentos dessa caminhada transmitiram de forma tão generosa parte do seu conhecimento: Gardênia Abbad, Josivânia Farias, Jorge Madeira e Diana Vaz de Lima.

Agradeço profundamente a todos os meus amigos da Assessoria do $\mathrm{DGP} / \mathrm{UnB}$, que tenho o privilégio de compartilhar grande parte do meu tempo todos os dias: Nara Cristina, Augusto, Elizânia, Mirlene, Édipo, Emelle, Marina, Francisco Góis, Cynara, Letícia, Elison, Luciana Pahl, Ivone e André, e aos demais colegas do Decanato de Gestão de Pessoas. Ressalto que essas pessoas não são simplesmente amigos, são verdadeiros anjos e minha segunda família. Não posso jamais deixar de agradecer à Decana de Gestão de Pessoas Dra. Maria Ângela Guimarães Feitosa, pela compreensão e força. Agradeço, ainda, aos meus colegas de outros Decanatos: Alexandre e Maria Inez, ambos do DPO e ao Joardo (DCF).

Agradeço especialmente ao Magnífico Reitor e a Vice-Reitora da Universidade de Brasília, Prof. Dr. Ivan Camargo e Profa. Dra. Sônia Báo, respectivamente, e também aos professores doutores Gardênia Abbad, Josivânia Farias, Roberto Ellery, Antonio Júnior e Milene Takasago que colocaram esse louvável projeto em pleno funcionamento propiciando aos servidores Técnico-administrativos em Educação a oportunidade de cursar o mestrado profissional em Gestão de Finanças Públicas do Departamento de Economia da Universidade de Brasília. Para mim essa titulação é motivo de muito orgulho e honra.

Agradeço de coração a oportunidade! 


\section{RESUMO}

O objetivo deste trabalho é mensurar e avaliar a eficiência dos gastos nos cursos de graduação da Universidade de Brasília nos anos de 2008 a 2010. Para alcançar este objetivo foi utilizado o método não-paramétrico, denominado Análise Envoltória de Dados (DEA). Os dados utilizados para a realização deste estudo foram extraídos do Sistema Integrado de Administração de Recursos Humanos do Governo Federal (SIAPE), Sistema de Graduação da Universidade de Brasília (SIGRA/UnB) e do sítio oficial do Instituto Nacional de Estudos e Pesquisa Educacionais Anísio Teixeira (INEP). Os insumos (inputs) utilizados foram a média de formação geral dos alunos ingressantes que fizeram o Exame Nacional de Desempenho de Estudantes (ENADE); média salarial dos docentes com regime de dedicação exclusiva e a Relação Aluno Professor (RAP). Já como produto (output), utilizamos a média de formação geral dos alunos concluintes do Exame Nacional de Desempenho de Estudantes (ENADE). Primeiramente, estimamos as fronteiras técnica e de escala, o que possibilitou ordená-los com maior eficiência técnica e de escala. Pelos resultados foi possível observar que os cursos de Relações Internacionais, Serviço Social, Enfermagem, Agronomia, Farmácia, Medicina, Odontologia e Design são os que apresentaram maior eficiência técnica, enquanto os cursos de Enfermagem e Serviço Social apresentam maior eficiência de escala.

Palavras-chave: Gastos. Cursos da UnB. Eficiência. DEA. 


\begin{abstract}
The objetive of this work is to measure and evaluate the efficiency of spending in undergraduate courses at the University of Brasilia in 2008 to 2010. To achieve the results and comparisons as the efficiency of public spending in analyzed courses was used the method not parametric, called Data Envelopment Analysis (DEA). The data used for this work were extracted from the System of Human Resources Management of the Federal Govermment (SIAPE), System Graduate of the University of Brasilia (SIGRA/UnB) and the official website of the National Institute of Educational Studies and Research Anísio Teixeira (INEP). The inputs used were the average overall formation of the entering students who took the National Examination of Student Performance (ENADE); average wage of the professoriate with exclusive dedication and the Relationship Student Teacher (RAP), being compared with the output which is the average of the general education of the students who completed National Examination of Student Performance (ENADE). In the outcome was established a ranking of courses with higher technical efficiency and efficiency of scale, and after data analysis, it is evident that the undergraduate courses of International Relations, Social Work, Nursing, Agronomy, Pharmacy, Medicine, Dentistry and Design are the ones that showed technical efficiency, whereas the undergraduate courses of Nursing and Social Work present efficiency of scale.
\end{abstract}

Keywords: Expenses. Courses at UnB. Efficiency Frontier. DEA. 


\section{LISTA DE ILUSTRAÇÕES}

Quadro 1 - Variáveis utilizadas para cálculo da eficiência dos cursos da 31 Universidade de Brasília

Figura 1 - Eficiência Técnica e de Escala $\quad 49$

Figura 2 - Função Produção

Figura 3 - Eficiência Técnica $\quad 54$ 


\section{LISTA DE TABELAS}

Tabela 1 - Indicadores de Desempenho da Universidade de Brasília - 20082010

Tabela 2 - Relação dos cursos avaliados neste estudo identificados por número de Decision Making Unit (DMU) - 2008-2010 30

Tabela 3 - Relação dos cursos avaliados e as variáveis (inputs) utilizadas 33

Tabela 4 - Valores usados para cálculo da Relação Aluno Professor (RAP) 34

Tabela 5 - Média salarial (mensal) dos docentes Dedicação Exclusiva 35

Tabela 6 - Nota (média) de formação geral dos alunos ingressantes do Exame 36 Nacional de Desempenho de Estudantes (Enade)

Tabela 7 - Nota (média) de formação geral alunos concluintes do Exame

Nacional de Desempenho de Estudantes (Enade)

Tabela 8 - Ranking relativo a Eficiência Técnica (ET) 53

Tabela 9 - Percentual de cursos por níveis de eficiência e ineficiência 54

Tabela 10 - Classificação dos cursos por Grupo de acordo com escores 55

Tabela 11 - Cursos do Grupo I e suas variáveis (inputs e output) 57

Tabela 12 - Cursos do Grupo II e suas variáveis (inputs e output) 58

Tabela 13 - Cursos do Grupo III e suas variáveis (inputs e output)

Tabela 14 - Relação dos cursos com ineficiência técnica 60

Tabela 15 - Redução média de inputs $\quad 61$

Tabela 16 - Ranking de Eficiência de Escala $\quad 62$

Tabela 17 - Comparação Ranking de Eficiência Técnica e de Escala 64 


\section{LISTA DE ABREVIAÇÕES E SIGLAS}

BCC - Retornos Variáveis de Escala

CCR - Retornos Constantes de Escala

$\mathrm{CF}$ - Constituição Federal

CRS - Constant Returns to Scale

DE - Dedicação Exclusiva

DEA - Data Envelopment Analysis

DF - Distrito Federal

DMU - Decision Making Unit

ENADE - Exame Nacional de Desempenho de Estudantes

ET - Eficiência Técnica

FDH - Free Disposable Hull

IFES - Instituições Federais de Ensino Superior

INEP - Instituto Nacional de Estudos e Pesquisas Educacionais Anísio Teixeira

IPEA - Instituto de Pesquisa Econômica Aplicada

MEC - Ministério da Educação

PIB - Produto Interno Bruto

RAP - Relação Aluno Professor

REUNI - Programa de Reestruturação e Expansão das Universidades Federais

SIAPE - Sistema Integrado de Administração de Recursos Humanos

SIGRA - Sistema de Graduação da UnB

UnB - Universidade de Brasília

VRS - Variable Returns to Scale 


\section{SUMÁRIO}

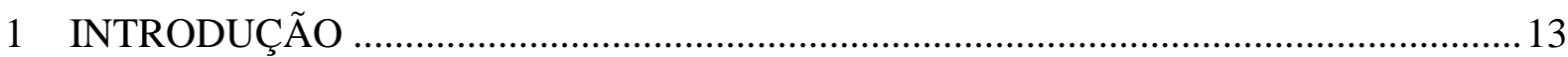

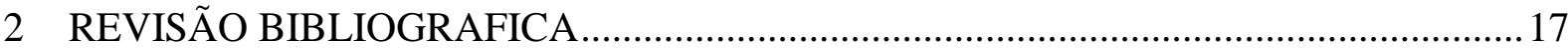

2.1 A importância da educação e os seus reflexos na economia ....................................... 17

2.2 Melhoria dos gastos públicos com educação em prol da eficiência..............................20

2.3 O financiamento público garantido para educação e as fontes próprias de arrecadação de recursos providas devido a autonomia universitária ........................ 23

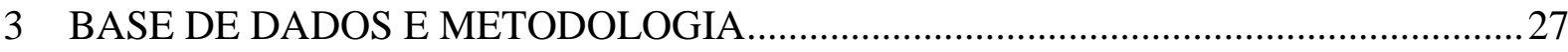

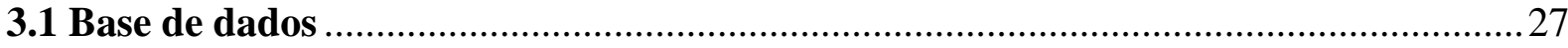

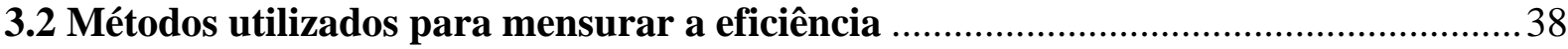

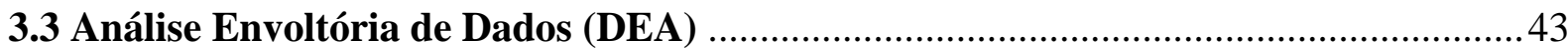

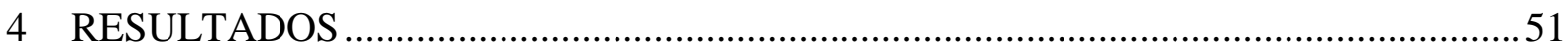

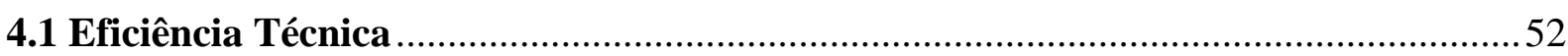

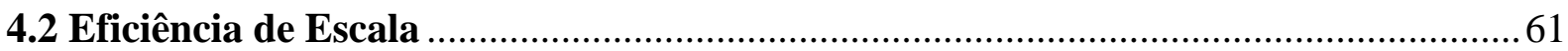

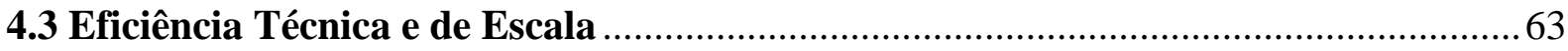

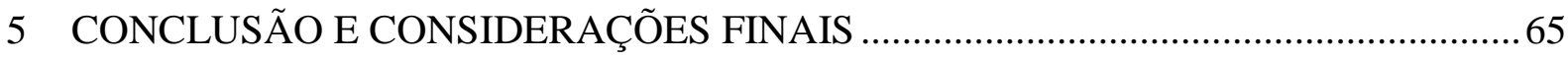

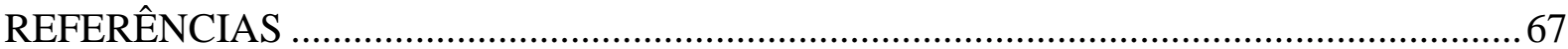




\section{INTRODUÇÃO}

O atual cenário econômico do país juntamente com a escassez de recursos colabora para uma forte atenção relativa a eficiência dos gastos públicos, principalmente com a educação.

Sabe-se que o Índice de Atividade Econômica do Banco Central (IBC-Br), considerado uma "prévia" do Produto Interno Bruto (PIB), em maio deste ano em comparação com mesmo mês de 2014 teve uma queda de 4,75\%. Além disso, considerando um comparativo com o período de janeiro a março de 2014 a economia brasileira encolheu 1,6\%, sendo o pior resultado desde o segundo trimestre do ano de 2009 (SARAIVA e KLEIN, 2015). A projeção para crescimento do PIB, para o primeiro trimestre de 2015, foi de - 1,1\%. Ainda, segundo dados do Banco Central do Brasil, o crescimento da indústria está estimado em - 3,0\%, destacando-se os recuos de 4,9\% na indústria de transformação e de 3,9\% na construção civil. A atividade fabril recuou $0,9 \%$ em fevereiro deste ano, o setor de bens de capital apresentou $4,1 \%$, seguido pelo setor de bens de consumo semi e não duráveis que foi de $-0,5 \%$, de bens de consumo duráveis - 0,4\% e de bens intermediários - 0,1\% (BCB, 2015). Dessa forma, visando minimizar a crise orçamentária o Governo Federal efetuou um corte nas verbas destinadas às Universidades Federais na ordem de mais de 7 bilhões de reais, o que representa uma redução de aproximadamente $30 \%$.

Reflexos desse corte no orçamento afetou diversas universidades, como por exemplo a Universidade Estadual de Campinas (Unicamp) e a Universidade Estadual Paulista (Unesp) que suspenderam contratações e não concederam aumentos salariais, por meio de progressões na carreira dos docentes. Na Universidade de São Paulo (USP), houve redução das despesas de custeio e bloqueio nas contratações, além de propiciar incentivos ao Programa de Demissão Voluntária (TAKAHASHI, F. e TUROLLO JR, 2015). Já na Universidade Federal do Rio de Janeiro (UFRJ), houve o fechamento do Museu Nacional por falta de pagamento dos empregados terceirizados. Quanto as Universidades de Brasília e de Campina Grande houveram cortes nas verbas de bolsas estudantis e atrasos nos pagamentos das contas de água e energia elétrica.

Diante do exposto, faz se necessário que os gestores públicos busquem formas de alcançar os melhores resultados com os menores gastos, ou seja, garantindo a qualidade do gasto público que nada mais é que a denominada "eficiência", conforme estudos de Ferreira (1996), Cândido Jr. (2001) e Mazoni (2005). Assim, sob o ponto de vista da análise microeconômica e de eficiência, Farrel (1957) afirma que uma produção é eficiente 
tecnologicamente se não existir uma outra forma variável de produzir mais com a mesma quantidade de fatores ou produzir a mesma quantidade de produtos utilizando menor quantidade de fatores. Ora, para que seja possível avaliar a fronteira de eficiência podem-se utilizar duas abordagens distintas: a estatística (ou econométrica) de métodos paramétricos ou a matemática (ou determinística) de métodos não-paramétricos.

$\mathrm{Na}$ abordagem estatística ou econométrica, por exemplo, pode-se utilizar a fronteira estocástica, cujo diferencial é a introdução do "erro" . Nesse modelo de fronteira, permite-se a estimação de erros padronizados e testes de hipóteses usando o método de máxima verossimilhança, o que não é permitido usando modelos determinísticos. Para Sengupta (1999), na abordagem econométrica, a estimação de eficiência tecnológica de produção é feita por meio de parâmetros testados com base em erros padrões. No entanto, para o autor existem algumas desvantagens no uso dessa abordagem, tais como: o erro de má-especificação, que muitas vezes é causado pela forma funcional da função de produção. Além disso, outra desvantagem é que a mensuração de eficiência em que há muitos insumos e produtos não é de fácil aplicação no modelo paramétrico. Já na abordagem matemática (ou determinística) utilizam-se métodos de programação linear. Essa abordagem é adequada em situações em que existam múltiplos insumos e produtos, evitando erros de especificação o que a torna vantajosa, segundo Sengupta (1999). Nesse tipo de abordagem podem ser efetuados os métodos de Análise Envoltória dos Dados (DEA) ou Free Disposable Hull (FDH).

Por fim, para cumprirmos o objetivo deste estudo que é avaliar e mensurar a eficiência dos gastos nos cursos de graduação da Universidade de Brasília nos anos de 2008 a 2010, utilizamos o método de Análise Envoltória dos Dados, considerando que esse método permite a utilização de diversos tipos de variáveis quantitativas e qualitativas tornando-o bem apropriado para o estudo proposto. Além disso, sabemos que o modelo DEA, segundo Costa, Ramos e Souza (2010) tem sido utilizado por diversos países para medir a eficiência relativa a educação. Assim sendo, utilizamos os insumos (inputs) relativo as seguintes variáveis: a média salarial dos docentes com regime de dedicação exclusiva, a média de formação geral dos alunos ingressantes que do fizeram o Exame Nacional de Desempenho de Estudantes (Enade) e a Relação Aluno Professor (RAP). Quanto a variável relativa ao produto (output) utilizamos a média de formação geral dos alunos concluintes do Enade.

Inicialmente foram selecionados 42 (quarenta e dois) cursos, ou seja, a totalidade dos cursos avaliados pelo Enade nos referidos anos. Entretanto, por falta de informações

\footnotetext{
${ }^{1} \mathrm{O}$ termo erro captura os desvios da função fronteira.
} 
desagregadas nas fontes de coletas de dados foram perdidas algumas observações, com isso, serão demonstrados os resultados da análise de 27 (vinte e sete) cursos, quais sejam: Administração; Agronomia; Arquivologia; Bacharelado em Ciências da Computação; Biologia; Ciências Contábeis; Design; Direito; Enfermagem; Engenharia Civil; Estatística; Farmácia; Filosofia; Física; Geografia; História; Jornalismo; Matemática; Medicina; Música; Nutrição; Odontologia; Publicidade e Propaganda; Química; Relações Internacionais; Serviço Social e Teatro. Após análise dos dados, verificamos que os cursos de Relações Internacionais, Serviço Social, Enfermagem, Agronomia, Farmácia, Medicina, Odontologia e Design estão sobre a fronteira de eficiência técnica. Enquanto, somente os cursos de Enfermagem e Serviço Social apresentaram eficiência de escala.

Este trabalho encontra-se organizado da seguinte forma: no Capítulo 1, a introdução traz um breve histórico de toda pesquisa, além da motivação do estudo e o objetivo. No capítulo 2, apresentamos a revisão bibliográfica que trata dos principais assuntos que motivaram esse trabalho com os principais autores. O capítulo 3 apresenta a metodologia e os dados usados neste estudo. O capítulo 4 apresenta os resultados da análise e, por fim, o capítulo 5 traz a conclusão e as considerações finais indicando a contribuição deste trabalho. 


\section{REVISÃO BIBLIOGRAFICA}

Neste capítulo serão tratados os principais assuntos que motivaram este trabalho, tais como: a importância da educação e seus reflexos na economia; os gastos públicos com educação, os benefícios da descentralização das políticas na área educacional e na geração da eficiência; o financiamento da educação e suas vantagens no que tange a arrecadação de recursos nas fontes próprias e autonomia universitária.

\subsection{A importância da educação e os seus reflexos na economia}

A educação é fator fundamental para a capacitação do capital humano e, por conseguinte, responsável pelo crescimento econômico. Sabe-se que o crescimento e o desenvolvimento econômico estão intimamente ligados à educação. Para Barros e Mendonça (1997) se uma pessoa aumenta seu nível educacional consequentemente tende a aumentar seus salários, uma vez que sua produtividade também aumentará. Além disso, segundo os citados autores, a educação proporciona às pessoas uma elevação na expectativa de vida, uma vez que passam a gerir os seus recursos familiares com mais eficiência, efetuando o seu planejamento familiar, com intuito de aumentar sua qualidade de vida, colaborando, assim, para uma diminuição no grau de pobreza da população e elevação da situação de crescimento e desenvolvimento econômico do país. Ou seja, os impactos que aumentos no capital humano exercem sobre o desenvolvimento socioeconômico do país são o que motivam a realização de investimentos nessa área. A educação não influencia apenas as condições de vida daqueles que educam, mas sim, geram externalidades positivas a toda sociedade.

Nesse sentido, a expansão educacional possibilita maior equidade e eficiência econômica tornando-se essencial para o favorecimento do desenvolvimento e crescimento econômico sustentado de uma nação Barros, Henriques e Mendonça (2002). Para Hagen (1971) a educação de uma pessoa torna mais eficiente o trabalho das outras, e um país pode compensar a falta de recursos naturais por meio de um sistema de ensino melhorado. Diante disso, é consenso que a educação é a mola propulsora do crescimento econômico e, portanto, conforme Zanmaria e Castilho (2006) deve-se investir neste bem. O investimento nas pessoas e em seus conhecimentos acaba tornando-se um fator decisivo para garantir o bem-estar humano. As habilidades individuais que são adquiridas pelas pessoas são básicas para se conseguir alcançar o progresso econômico Schultz (1987). 
Diante dessa demonstração da importância da educação para formação do capital humano, registra-se que as primeiras escolas de ensino superior brasileiras foram fundadas no ano de 1808 com a chegada da família real portuguesa. Contudo, até a proclamação da república, ocorrida em 1889, o ensino superior desenvolveu-se muito lentamente, pois seguia o modelo de formação dos profissionais liberais em faculdades isoladas, e visavam assegurar um diploma profissional com direito a ocupar postos privilegiados, em um mercado de trabalho restrito. Assim, a ampliação do ensino superior era contida pela capacidade de investimentos do Governo Central e dependia exclusivamente de vontade política (MARTINS, 2002).

Finalmente, no ano de 1920, no Rio de Janeiro, foi fundada a primeira Universidade Brasileira e definitivamente, marcou os rumos da educação superior no Brasil, sinalizando para o estabelecimento de uma nova era. A partir daí, deflagram-se alguns momentos importantes na história da educação brasileira. Nesse contexto, surgiram e desenvolveram-se as instituições de Ensino Superior no Brasil buscando atender ao mercado que solicitava profissionais qualificados, ao mesmo tempo em que se buscava criar sua própria identidade enquanto sistema de educação, que é considerado até hoje, como uma das mais preciosas construções do Brasil republicano (ATAÍDE, 2014).

Ora, há muitas razões que podem justificar o fomento estatal à educação superior: o fato de a educação ser um grande investimento em capital humano; a provisão de políticas que busquem equidade e a existência de informação imperfeita no mercado de crédito, o que pode levar a uma oferta insuficiente de financiamentos aos estudantes, conforme Vonbun e Mendonça (2012). Diante de todo exposto, e considerando que esse tema sempre esteve em destaque nas Constituições Federais Brasileiras, faremos uma breve passagem pelas suas citações. Inicialmente, a primeira legislação educacional no Brasil surgiu com a Constituição Imperial de 1824, que trazia em seu artigo 179, a seguinte expressão: “a instrução primária é gratuita a todos os cidadãos”. Entretanto, esse assunto voltou a aparecer somente na Constituição de 1934, com entendimento sobre a educação como formação da personalidade. Em 1937, foi introduzida nas normas à educação gratuita, obrigatória e solidária. Naquela época, a educação era vista como dever precípuo dos pais de ministrá-la cabendo ao Estado somente o dever de colaborar e complementar as deficiências da educação particular. Citamos o descrito no artigo 166 da Constituição de 1946, que assim mencionava: “A educação é direito de todos e será dada no lar e na escola. Deve inspirar-se nos princípios de liberdade e nos ideais de solidariedade humana". No que pese, que em 1946 a educação era também 
oferecida pelo Estado, somente na Constituição de 1967 a educação aparece de forma mais estruturada com os direitos econômicos e sociais. Todavia, transcorridos dois anos, a Constituição sofreu alterações de forma considerável no que tange ao direito à educação. Tal fato demonstrou uma forte repressão que se instaurou no país após o golpe de Estado de 31 de março de 1964 (época dos governos militares) (MENEZES, 2001).

Sabe-se que durante as décadas de 1960 e 1970, havia um domínio e um controle político de governos autoritários oriundos do golpe militar, uma das características principais dessa Administração foi a montagem de mecanismos de poder fortemente centralizada, que mantinha o comando concentrado em um reduzido núcleo dirigente. E, dali emanava todas as orientações para a gestão das políticas públicas em geral. Somente a partir do final dos anos 1970 e início dos anos 1980, houve uma crise de sustentação do regime militar, sendo então substituído por governos civis, e assim reestabelecida a democracia.

No decurso dos anos 1980, com advento da Constituição da República Federativa do Brasil, promulgada em 5 de outubro de 1988, volta a vigorar o Estado de direito, a liberdade de expressão e a institucionalidade democrática no país (MENEZES, 2001) e com ela a inclusão do tema "educação". Por exemplo, os artigos 205 a 214 da referida Constituição, reestabelecem objetivos e diretrizes para o sistema educacional do país apontando os titulares passivos do direito à educação (BRASIL, 1988). Já o artigo 206, estabelece a forma como deve ser desenvolvida a educação no Brasil sempre pautada nos Princípios da Igualdade e Liberdade, vinculando tanto as entidades públicas quanto as privadas, de modo que venha a ser garantida uma boa prestação do serviço educacional de forma isonômica (SILVA, 2008). Sabe-se que a educação superior no Brasil deu um salto considerável após a promulgação da Constituição Federal de 1988, vejamos o que diz Neves (2012, p. 2):

\footnotetext{
Nos últimos vinte anos, o Brasil assistiu a um notável processo de crescimento de seu ensino superior. No começo dos anos 90 do século passado, somavam-se 1.540.080 estudantes matriculados no ensino superior no Brasil. Esse número saltou para 2.694.245 de estudantes em 2000 e para 6.379.299 no ano de 2011.
}

Hoje o marco legal da política educacional brasileira não é representado somente pela Constituição Federal de 1988 (BRASIL, 1988), mas também pelo Estatuto da Criança e do Adolescente, Lei n. 8.069, de 13 de julho de 1990 (BRASIL, 1990); pela Lei de Diretrizes e Bases da Educação Nacional (LDB), Lei n. 9.394, de 20 de dezembro de 1996 (BRASIL, 1996); e por meio de Emendas Constitucionais e outros diversos conjuntos de normas infraconstitucionais e resoluções do Conselho Nacional de Educação (CNE). Esse arcabouço jurídico assegura a todos os brasileiros as condições formais para o exercício do direito básico 
à educação, especialmente ao ensino fundamental, além de fixar a atual estrutura de responsabilidades e competências para a oferta de educação no Brasil (CASTRO e DUARTE, 2008). Investimento nas pessoas e em seus conhecimentos acaba tornando-se um fator decisivo para garantir o bem-estar humano. As habilidades individuais que são adquiridas pelas pessoas são básicas para se conseguir alcançar o progresso econômico (SCHULTZ, 1987). Os impactos que aumentos no capital educacional exercem sobre o desenvolvimento socioeconômico do país são o que motivam a realização de investimento nesta área (BARROS e MENDONÇA, 1997).

Por fim, Castro (2001) faz um paralelo entre educação e o desenvolvimento econômico no Brasil, revelando que após a metade do século XX a economia acelera, no entanto, a educação se mantém a níveis de países subdesenvolvidos. Assim, no final do mesmo século há uma visão de que tem que haver um maior grau de educação.

\subsection{Melhoria dos gastos públicos com educação em prol da eficiência}

A preocupação com os efeitos dos gastos públicos na economia é recorrente, sobretudo com os impactos deles sobre o crescimento econômico. Segundo estudo de Gonçalves (2013), o crescimento dos gastos públicos no Brasil vem acompanhando a tendência mundial, expandindo-se de forma considerável, tanto em relação ao volume como em relação à sua participação como proporção do Produto Interno Bruto.

Para Araújo, Monteiro e Cavalcante (2010), o Brasil nos últimos 50 anos apresentou considerável expansão do setor público, o que resultou em um crescimento significativo do volume de despesa do governo e uma maior participação das despesas totais no PIB do país. Em consequência do aumento das despesas, houve também elevação no volume total de recursos necessários ao financiamento da expansão das atividades do governo. Estudos sobre a evolução dos gastos públicos no Brasil, no período de 1980 a 2006, efetuados por Amarante e Moreira (2009), confirmam que o país apresenta uma trajetória ascendente no comportamento dos gastos governamentais, além de uma participação cada vez maior no PIB. Apontam que as prioridades governamentais, referente a alocação de recursos, tiverem uma considerável variação e uma forte elevação dos gastos sociais, bem como, a criação de novas funções relativas ao desporto, lazer e direitos da cidadania.

Ora, essa tendência de aumento do gasto público sem preocupar-se com a qualidade desse gasto estende-se para educação. Estudos de Castro e Leite (2006) revelam elevados 
custos por aluno do ensino superior brasileiro e ineficiência na gestão de programas de graduação nas universidades. Para os citados autores, a origem dos problemas não está nas universidades, mas sim nas regras sob as quais operam, por exemplo, na mecânica orçamentária utilizada que não oferece quaisquer incentivos à eficiência. Além disso, não se verifica incentivos financeiros para matricular mais alunos, para redução da evasão escolar, para corte de custos e/ou para alocação mais eficiente de recursos públicos. Os autores demonstram que no Brasil, no ano de 2006, se gastava em educação algo equivalente a 4,3\% do PIB, percentual próximo da média dos países da Organização para Cooperação e Desenvolvimento Econômico (OCDE), e superior aos gastos de países da América do Sul com sistemas de educação mais bem-sucedidos, como por exemplo do Uruguai, Chile e Argentina. Ora, desse montante $21 \%$ são dedicados ao ensino superior, ou seja $0,82 \%$ do PIB, que, apesar de relativamente alto, não está fora de linha com os outros países. Só 16 (dezesseis) países no mundo gastam mais e praticamente todos são muito ricos. Sob essa medida, o Brasil gasta mais que o Japão, China e a Coréia. Contudo, tal fato não seria um problema se o $0,82 \%$ permitisse que muitos alunos estudassem na rede pública, o que não é o caso. Os gastos são efetuados, mas permite matricular somente $5,2 \%$ da população em idade universitária, sendo que com a média de $1 \%$ do PIB os países da OCDE matriculam cerca de $41 \%$ da população em idade de estar na universidade. Por outra ótica, $0,82 \%$ do PIB financia uma educação com um custo/aluno muito elevado, considerando que apenas Alemanha e Reino Unido gastam mais por aluno que o Brasil (CASTRO e LEITE, 2006).

Gastos elevados sem aplicação de critérios de qualidade, para Mendes (2008, p. 1): “a maior eficiência do gasto público é uma condição necessária para que o Brasil possa obter mais crescimento econômico, menor desigualdade, mais oportunidade de trabalho, menos violência e uma vida mais longa e recompensadora para a população". Bertê, Borges e Brunet (2009) afirmam que para tornar os gastos públicos com educação eficazes é necessário um acompanhado mais criterioso e de qualidade, visto que maiores gastos devem proporcionar a eficiência e a igualdade nos sistemas de ensino.

Sabe-se que existe um longo caminho a ser percorrido para que se possa ocorrer uma melhoria generalizada na eficiência do gasto público no Brasil, principalmente na educação, mas para que isso seja possível, o primeiro passo é dimensionar e mensurar a magnitude do desperdício de recursos públicos. Sem essa análise de quanto se gasta a mais que o necessário, dificilmente o governo poderá estabelecer metas para redução desses desperdícios. Ora, diversos estudos nos levam a compreender e afirmar que à medida que a sociedade se 
desenvolve a demanda por serviços públicos de qualidade aumentam, ou seja, eleva-se a exigência por serviços públicos mais eficientes e que atendam a todas as necessidades da população. Sendo assim, diante desse anseio crescente da sociedade pela provisão de serviços públicos de qualidade, entendemos que para melhor alcançar os resultados esperados, essa responsabilidade pode ser dividida por diferentes níveis de governo, tais como: a União, os estados e/ou municípios.

Nessa linha, Duarte et al. (2015) entendem que a descentralização serve para melhorar a qualidade do gasto por meio de uma gestão mais assertiva e eficiente do custo e benefício de cada bem e de cada serviço público.

A provisão descentralizada para oferta de bens públicos torna o gasto público mais eficiente. Ora, entende-se que a oferta de serviços públicos com ganhos de escala como por exemplo a educação, bem como a arrecadação de tributos, é competência da União. No entanto, a responsabilidade pela provisão de alguns serviços públicos poderá ser efetuada pelos municípios, uma vez que devido sua proximidade com os cidadãos, garantirá um melhor conhecimento de suas reais necessidades o que facilitará a tomada de decisões em prol da população. Por exemplo, é o caso da educação no Brasil, onde o ensino fundamental fica a cargo dos municípios, pois devido a extensão geográfica do nosso país seria inviável uma administração centralizada, além disso, a proximidade da administração escolar com os pais permite um melhor atendimento da demanda local, segundo Duarte et al. (2015). Por fim, nem tão distante e nem tão próximo da sociedade se encontra os estados que também podem efetuar esse papel. Dessa forma, entendemos que o processo de transferência de poder e responsabilidades de gestão da União para os estados e municípios chamada pela economia como descentralização, tema incluso na literatura como Federalismo Fiscal, propiciará maior eficiência econômica, bem-estar da sociedade e transparência na aplicação de recursos.

Finalmente, reforçando a ideia de descentralização em prol da eficiência na aplicação dos recursos públicos, sabe-se que os governos militares foram marcados por administrações excessivamente centralizadoras em nível federal, tanto na gestão como na formulação das políticas de diversos setores, entre eles a educação. A gestão e o controle na aplicação dos recursos constituíam-se, assim, em importante instrumento de barganha e controle político, que permitia a manutenção e a perpetuidade do poder de governantes e de políticos aliados. Entretanto, em meados da década de 1990, argumentava-se em defesa da descentralização da política educacional com base no fato de que ela otimizaria recursos pela eliminação de atividades-meio; fomentaria uma efetividade maior das políticas, já que transferiria para a 
ponta dos sistemas, ou seja, para os beneficiários, a responsabilidade de estabelecer as prioridades a serem atendidas; e tornaria o processo mais transparente, pois permitiria à população local acompanhar e fiscalizar a devida aplicação dos recursos e a prestação dos serviços. Esse foi o discurso que legitimou o estabelecimento das novas diretrizes que, ao longo da década de 1990, foram institucionalizadas para fomentar a descentralização das políticas públicas. Sua trajetória foi ascendente, partindo do governo com o moderno discurso que reivindicava a descentralização como medida imprescindível para alcançar a eficiência na prestação de serviços sociais.

\subsection{O financiamento público garantido para educação e as fontes próprias de arrecadação de recursos providas devido a autonomia universitária}

As Instituições Federais de Ensino Superior (Ifes) são financiadas por recursos públicos oriundos do Fundo Público Federal (FPF), que é responsável por financiar programas governamentais relacionados à educação, saúde, saneamento, habitação, assistência social, etc. Os recursos deste Fundo são provenientes da arrecadação de impostos, taxas e contribuições pagos pela sociedade.

O financiamento da educação está previsto em lei para todas as esferas do governo, e corresponde a aplicação de um percentual mínimo anual obrigatório à União, DF, estados e municípios. Para calcular o valor da capacidade de financiamento público associado à área educacional, admite-se como hipótese que os três níveis de governo respeitam essa imposição legal:

- União vincula à educação, já descontados os $20 \%$ da Desvinculação das Receitas da União (DRU), 18\% dos recursos oriundos da receita de impostos federais a ela destinados, de acordo com o artigo 212 da Constituição Federal de 1988;

- Estados vinculam à educação $25 \%$ das receitas de impostos que arrecadam, como também daquelas que lhes são transferidas, de acordo com o artigo 212 da CF/88;

- Municípios vinculam à educação 25\% das receitas resultantes de impostos, o que inclui os recursos provenientes de transferências, de acordo com o artigo 212; e

- Contribuição social do salário-educação (quotas estadual e federal). Ressalte-se que, para efeito desse cálculo, não estão sendo considerados recursos provenientes das contribuições sociais, operações de crédito realizadas com organismos 
internacionais, recursos próprios arrecadados por algumas instituições, entre outros.

Tais fontes vão compor o que denominamos de financiamento flexível.

Para Velloso (2000) as formas de alocação dos recursos públicos destinados à educação superior são divididas em financiamentos: básico e suplementar. O financiamento básico, subdivide-se em quatro modelos, mas podem apresentar-se de forma concomitante em um mesmo país, quais sejam: $i$ ) incremental; ii) fórmulas; iii) contratos de gestão; e $i v$ ) subsídios a alunos. O primeiro modelo, chamado incremental ou inercial, funciona como uma repetição dos valores das verbas utilizadas no ano anterior de cada instituição. O segundo modelo denominado por fórmulas, utiliza o número de docentes e alunos, e também indicadores de desempenho a fim de obter índices de eficiência. O terceiro modelo de contrato de gestão, se orienta pelos objetivos de determinada política pública, cujos recursos são definidos por meio de contratos de gestão firmados entre as instituições e governo, ou, ainda, com setores privados. No quarto e último modelo, denominado de subsídios a estudantes, baseia-se nas anuidades por eles pagas (no caso de instituições privadas) oriundo de empréstimos subsidiados pelo Estado, sendo a dívida resgatada em alguns anos após a conclusão dos estudos.

Por fim, esses modelos de financiamento das Ifes se mostraram insuficientes para o atendimento das crescentes demandas das universidades. Dessa forma, ao longo da década de 90 ampliou-se em quantidade e volume a captação de recursos financeiros por intermédio das chamadas fontes próprias de recursos, ou autofinanciamento das Ifes. As variadas opções para captação de recursos foi a solução encontrada pelas universidades como forma de complementar o orçamento oriundo do Tesouro. Dentre as atividades oferecidas, destacamos: assessorias, prestação de serviços, a comercialização de bens, realização de concursos, oferta de cursos de especialização e os projetos de cooperação, todas essas atividades têm sido utilizadas para geração de receitas. No entanto, apesar de o autofinanciamento das Ifes está sendo praticado em todo país, esse instrumento vem sendo objeto de críticas frequentes por parte das associações de docentes, que entendem que os instrumentos de captação de recursos próprios, muitas vezes envolvendo complementação salarial e fundações de direito privado, constituem-se em mais um passo para a privatização da universidade pública, criando indesejável heteronomia dentro das instituições, conforme Teixeira (2002) e Americano da Costa (2002). Por outro lado, há autores que defendem que a geração de recursos próprios é uma importante fonte alternativa de financiamento para sobrevivência da universidade pública e gratuita Corbucci e Marques (2003). Afirmam que a captação de recursos funciona como 
uma alternativa para a sobrevivência da universidade pública e gratuita, inclusive complementando salários de docentes e técnicos, buscando uma intensificação de relações da instituição com os mais variados segmentos da sociedade. Nessa linha, Figueiras (1998) considera que existe uma necessidade cada vez mais intensa de as universidades se relacionarem com os seguimentos econômicos e sociais.

Ora, no que pese a contenção orçamentária que as universidades federais estão submetidas desde a segunda metade da década de 90, estudos e pesquisas realizadas pelo Instituto de Pesquisa Econômica e Aplicada (IPEA) evidenciam que as instituições têm apresentado melhorias em termos de desempenho e produtividade. Dessa forma, entendemos que as arrecadações de recursos próprios efetuados pelas Ifes podem superar a falta de recursos disponíveis pelo governo, assegurando a qualidade do ensino, a expansão do acesso e o aumento da produção técnico-científica.

Segundo Corbucci e Marques (2003) e Velloso e Marques (2005), a Universidade de Brasília se destaca no que diz respeito ao autofinanciamento, uma vez que no conjunto das universidades públicas, esta possui a maior proporção de gastos com recursos diretamente arrecadados (com relação ao total de suas despesas). Assim, fatores internos teriam concorrido para ampliação da geração de recursos próprios na UnB, tais como: $i$ ) administração mais eficiente do patrimônio universitário; ii) ampliação do número de parcerias realizadas com instituições públicas e privadas; $i i i)$ aumento do número de imóveis residenciais alugados; $i v$ ) redução dos gastos com pagamento de dívidas mantidas com a Caixa Econômica Federal desde a época da construção de novos prédios residenciais no campus universitário; e v) administração centralizada da previsão da receita a ser captada pelas unidades descentralizadas. Os autores destacam ainda, que independentemente das razões que fomentam o crescimento das iniciativas voltadas à geração de recursos próprios pelas Ifes, há de se reconhecer que, no caso específico da UnB, essa fonte de financiamento é imprescindível para assegurar o próprio funcionamento da Instituição. Velloso e Marques (2005, p. 675), afirmam:

A UnB vem dependendo, cada vez mais, de recursos próprios para sua manutenção e desenvolvimento. Nos últimos cinco anos, nos gastos com outras despesas correntes, os recursos diretamente arrecadados foram equivalentes a mais que o triplo do aportado pelo MEC na categoria. Nessa categoria de gastos, complementares aos de pessoal e indispensáveis à manutenção e ao desenvolvimento da instituição, vem sendo crescente a dependência de receitas diretamente arrecadadas [...].

Sobrinho (2001, p. 167) entende que, quando a universidade se aproxima demasiadamente das empresas, pode terminar se confundindo com elas, ao passo que, se 
mantém uma distância crítica, os significados concretos e a relação adquirem consistência, e a "universidade crítica preserva sua identidade e autonomia". Sabe-se que a universidade pública é uma instituição que desfruta de autonomia acadêmica, conforme versa o artigo 207 da $\mathrm{CF} / 88$, e opera por sistemas de gestão colegiada, pois se trata de uma instituição formada por subunidades que se autorregulam. Entretanto, para Borges (2005), essa autonomia vem sendo exercida de modo bastante limitado. Sugerindo para que alcance definitivamente sua autonomia universitária que sejam criados critérios de distinção na distribuição de recursos de modo que considerem aspectos regionais e o esforço que cada instituição faz no sentido de formular projetos mais abrangentes. Destaca-se que as universidades públicas brasileiras são regidas por sistemas muito distintos em cada segmento, ou seja, a graduação é burocrática, formalista e frequentemente politizada. Já a pós-graduação, é controlada pelos prêmios e sanções de um sistema de quase mercados de Ciência e Tecnologia, onde os incentivos são administrados pela Coordenação de Aperfeiçoamento de Pessoal de Ensino Superior (Capes), pelo Conselho Nacional de Desenvolvimento Científico e Tecnológico (CNPq), pela Financiadora de Estudos e Projetos (Finep) e por muitas outras instituições, programas e linhas de financiamento à pesquisa. Diante desse cenário, a pós-graduação e a pesquisa funcionam pelas regras meritocráticas do sistema de Ciência e Tecnologia (C\&T), enquanto o ensino de graduação permaneceu na velha estrutura burocrática do MEC. As fundações universitárias operam basicamente com regras de mercado, em especial, o sistema de pósgraduação e pesquisa, que com sua forma de atuação, demonstram que é possível montar um sistema público de âmbito nacional e de boa qualidade, conforme Hirschman (1970).

Entendemos que as universidades públicas federais brasileiras carecem de uma política de financiamento sustentável que atenda na sua plenitude as demandas exigidas para seus três eixos: ensino, pesquisa e extensão, e principalmente carecem de recursos ou, ainda, melhor aplicação dos recursos disponíveis para expansão de suas atividades zelando por sua qualidade. A CF de 1988 tem assegurado o direito de autonomia pelas Ifes, mas essa prerrogativa tem sido limitada por ações do próprio governo. 
Neste capítulo descrevemos o lócus do nosso estudo que é a Universidade de Brasília. Além disso, descreveremos algumas características importantes do Exame Nacional de Desempenho de Estudantes (Enade), que é uma das principais fontes de coleta de dados deste estudo. Em seguida, falaremos dos métodos disponíveis para mensuração de eficiência, e por fim descreveremos o modelo escolhido para este estudo: a Análise Envoltória de Dados (DEA) uma técnica não-paramétrica, de programação linear, utilizada amplamente para construção da fronteira de eficiência na área da educação.

\subsection{Base de dados}

Este trabalho teve como unidade de análise a Universidade de Brasília (UnB), criada no ano de 1961 para atuar como incentivadora de pesquisas e apoio à sociedade, comprometendo-se com a ética, com os direitos humanos, o desenvolvimento socioeconômico sustentável, a produção de conhecimento científico, cultural e tecnológico e com a transformação social.

Diante desse imenso papel econômico e social, e a fim de expandir os benefícios oriundos da educação, houve a efetivação para instalação de novos campi da Universidade de Brasília que se pautou em estudo que levou em conta as características econômicas e demográficas do DF e entorno (OLIVEIRA, 2013). Nesse contexto, em meio às políticas públicas de incentivo à educação, surgiu o Plano de Reestruturação e Expansão da Universidade de Brasília (REUNI), que se demonstrou capaz de suprir as necessidades de investimentos financeiros, para viabilizar a construção dos novos espaços físicos de cada novo campi, e ampliação do campus Darcy Ribeiro, e também, para contratação de novos servidores técnicos e docentes. O referido Plano de Expansão (REUNI) foi aprovado pelo Ministério da Educação e sua meta estabelecida para os anos de 2008 a 2012, o seu objetivo material central na UnB foi delimitado para aumento do número de vagas ofertadas e a criação de novos cursos capazes de atender a crescente demanda de estudantes, além de expandir a participação da comunidade em projetos político-pedagógicos e o estabelecimento de parcerias com Governo do DF (BRASIL,2007).

Atualmente a Universidade de Brasília é composta pelo campus Universitário Darcy Ribeiro, localizado na Asa Norte, e mais 03 (três) campi: Faculdade Planaltina (UnB/FUP); 
Faculdade do Gama (UnB/FGA) e Faculdade Ceilândia (UnB/FCE), localizados no entorno do DF. Vale ressaltar que nos anos analisados neste estudo (2008 a 2010), a UnB apresentou os seguintes indicadores de desempenho:

Tabela 1 - Indicadores de Desempenho da Universidade de Brasília - 2008-2010

\begin{tabular}{|c|c|c|c|}
\hline Indicadores de desempenho & 2008 & 2009 & 2010 \\
\hline Oferta de Cursos de Graduação - diurno e noturno & 98 & 115 & 134 \\
\hline Ingressantes - graduação - PAS, vestibular, outras vias & 6.628 & 8.017 & 8.366 \\
\hline Alunos regulares - graduação $-2^{\circ}$ semestre & 25.314 & 27.929 & 29.775 \\
\hline Formados - graduação & 3.513 & 4.319 & 4.202 \\
\hline Oferta de Cursos de Pós-Graduação & 156 & 185 & 152 \\
\hline Alunos registrados na Pós-Graduação $-2^{\circ}$ semestre & 4.945 & 5.149 & 5.635 \\
\hline Títulos outorgados - mestrado e doutorado & 1.340 & 1.288 & 1.132 \\
\hline Atividades de extensão - comunidade atendida & 18.000 & 108.000 & 24.000 \\
\hline
\end{tabular}

Fonte: UnB (2014).

Diante desses números podemos afirmar que são inúmeros os benefícios trazidos à economia regional e a sociedade pela proximidade da UnB. Sabe-se que a Universidade é fonte genuína de conhecimento e de transformação, cujo potencial inovativo é inerente e incontestável. Ressaltamos, o dito Cosmos (2013, p. 31) em seu estudo sobre a UnB:

a análise do impacto econômico das universidades sobre as regiões pode partir dos fluxos de renda locais ou considerar o impacto sobre a demanda agregada regional. Universidades têm papel no desenvolvimento econômico de uma região. Esse papel pode ser executado de diversas formas, e.g., a formação do capital humano da região, a produção do conhecimento, a função de incubadora de empresas como estimuladora do empreendedorismo. O processo ensino-aprendizagem basicamente é o que acaba sendo mais observado como atividade formal da universidade. Isso é facilmente visualizado pela população que acompanha o novo ambiente econômico, favorecedor de trabalhadores com maiores níveis de escolaridade.

Ora, mesmo diante das dificuldades de toda ordem, principalmente quanto à escassez de recursos públicos, escolhemos como lócus deste estudo a Universidade de Brasília, devido ao seu grande papel de formação do capital humano, além de sua extensa e comprovada contribuição para o desenvolvimento intelectual, científico, técnico, social e/ou cultural da sociedade. Contudo, para que este estudo fosse possível utilizamos dados do Exame Nacional de Desempenho de Estudantes (Enade), cujo objetivo é avaliar o desempenho dos estudantes com relação aos conteúdos programáticos previstos nas diretrizes curriculares dos cursos de graduação, às suas habilidades para ajustamento, às exigências decorrentes da evolução do conhecimento, às suas competências para compreender temas exteriores ao âmbito específico de sua profissão, ligados às realidades brasileira e mundial e a outras áreas de conhecimento. 
Resultados empíricos, efetuados para o ensino básico, que após aplicação de sistemas de avaliação de ensino esses locais obtiveram melhores desempenhos educacionais o que não ocorreu em locais onde não se aplicaram essa ferramenta de análise, conforme Hanushek e Raymond (2004).

Ora, sabemos que não é fácil mensurar resultados obtidos pelas universidades, por isso recorremos neste estudo dos dados, informações e notas do Enade. Cabe destacar, que o Enade é componente curricular obrigatório dos cursos de graduação, sendo o registro de participação do estudante uma condição indispensável para a emissão do histórico escolar. Sua aplicação é anual e direcionada aos alunos ingressantes e concluintes em cursos de graduação, de áreas definidas por amostragem pelo Ministério da Educação (MEC). Contudo, a periodicidade de aplicação em cada área é trienal. Ressalta-se que o Enade, é parte do Sistema Nacional de Avaliação da Educação Superior (Sinaes), e visa contribuir para a permanente melhoria na qualidade do ensino oferecido, servindo não somente para avaliação dos cursos de graduação, mas também para avaliação institucional das Instituições de Ensino Superior. O conceito Enade ${ }^{2}$ utiliza a estatística chamada afastamento padronizado. A nota final do curso depende de duas variáveis: o desempenho dos estudantes concluintes na formação geral e o desempenho dos estudantes concluintes no componente específico. Ora, a nota final da Instituição de Ensino Superior é a média ponderada da nota padronizada dos concluintes nos componentes específicos e de formação geral, onde a parte referente ao componente específico contribui com $75 \%$ da nota final, enquanto a parte de formação geral contribui com $25 \%$. O conceito é apresentado em cinco categorias que variam de 1 a 5 , sendo o 1 o resultado mais baixo e 5 o melhor resultado possível na área.

Para realização deste estudo utilizamos os dados do Enade para os anos de 2008, 2009 e 2010. Registra-se que participaram da amostra um total de 4.610 (quatro mil seiscentos e dez) estudantes, esses alunos foram distribuídos da seguinte forma: no ano de 2008 participaram 1.820 (um mil oitocentos e vinte); em 2009 foram 1.858 (um mil oitocentos e cinquenta a oito) e no ano de 2010 houve queda, participando somente 932 (novecentos e trinta e dois) alunos. Ora, devido a periodicidade trienal de cada área foi escolhido para este estudo os anos de 2008, 2009 e 2010, uma vez que tal período, possibilitou a análise de todas as áreas de formação dos alunos de graduação (humanas, exatas, biológicas, tecnologias). Além disso, cumpre informar que nos anos posteriores ao deste estudo, ou seja, a partir de 2011 , a avalição

\footnotetext{
${ }^{2}$ Maiores informações sobre o cálculo do Conceito Enade disponível em: <http://portal.inep.gov.br/educacaosuperior/indicadores/conceito-enade>. Acesso em: 10 mai 2015.
} 
dos alunos ingressantes passou a ser realizada somente pelo Exame Nacional do Ensino Médio (Enem). Tal fato foi relevante para escolha e decisão definitiva quanto aos anos escolhidos para análise.

Inicialmente, tentou-se estimar a eficiência dos 42 (quarenta e dois) cursos de graduação avaliados no Enade nos anos 2008 a 2010. No entanto, 15 (quinze) cursos não foram analisados por falta de dados desagregados disponíveis. Por exemplo, foram excluídos da amostra os cursos de "controle e automação", "eletrotécnica" e "telecomunicações" que no Enade apresentaram notas distintas. Isso quer dizer que, esses cursos apesar de apresentarem notas separadamente na avaliação do Enade estão vinculados ao curso de Engenharia Mecatrônica, que por sua vez, está vinculado na fonte de consultas (SIAPE), ao Departamento de Engenharia Mecânica. Ora, devido a essa unificação das informações no sistema não foi possível coleta o dado relativa à média salarial (mensal) dos docentes em regime de dedicação exclusiva, impossibilitando, assim, a análise para os referidos cursos. Outro curso excluído da amostra foi o de biblioteconomia, avaliado no ano de 2009, que também não foi analisado devido a indisponibilidade de dados desagregados nos sistemas de coleta de dados. O mesmo ocorreu para os cursos de Terapia Ocupacional, Teatro, Psicologia, Ciências Econômicas, Medicina Veterinária, Pedagogia, Letras, Engenharia Florestal, Arquitetura e Urbanismo e Ciências Sociais, todos eles excluídos da amostra.

Tabela 2 - Relação dos cursos avaliados neste estudo identificados por número de Decision Making Unit (DMU) - 2008-2010

\begin{tabular}{clccll}
\hline DMU & Cursos Avaliados & Ano & DMU & Cursos Avaliados & Ano \\
\hline $\mathbf{1}$ & Administração & 2009 & 15 & Geografia & 2008 \\
$\mathbf{2}$ & Agronomia & 2010 & 16 & História & 2008 \\
$\mathbf{3}$ & Arquivologia & 2009 & 17 & Jornalismo & 2009 \\
& Bacharelado em Ciência da & & & & \\
$\mathbf{4}$ & Computação & 2008 & 18 & Matemática & 2008 \\
$\mathbf{5}$ & Biologia & 2008 & 19 & Medicina & 2010 \\
$\mathbf{6}$ & Ciências Contábeis & 2009 & 20 & Música & 2009 \\
$\mathbf{7}$ & Design & 2009 & 21 & Nutrição & 2010 \\
$\mathbf{8}$ & Direito & 2009 & 22 & Odontologia & 2010 \\
$\mathbf{9}$ & Enfermagem & 2010 & 23 & Publicidade e Propaganda & 2009 \\
$\mathbf{1 0}$ & Engenharia Civil & 2008 & 24 & Química & 2008 \\
$\mathbf{1 1}$ & Estatística & 2009 & 25 & Relações Internacionais & 2009 \\
$\mathbf{1 2}$ & Farmácia & 2010 & 26 & Serviço Social & 2010 \\
$\mathbf{1 3}$ & Filosofia & 2008 & 27 & Teatro & 2009 \\
$\mathbf{1 4}$ & Física & 2008 & & & \\
\hline Fonte: Elaboração própria. & & & &
\end{tabular}


Foram feitas análises da eficiência técnica de 27 (vinte e sete) cursos de graduação (Tabela 2). Ressalta-se que os referidos cursos ou Unidades Tomadoras de Decisão, chamadas de $\mathrm{DMUs}^{3}$, estão classificados em ordem alfabética.

Para a realização da pesquisa foram utilizados dados secundários para coleta e construção das variáveis relativas aos insumos (inputs), tais como: os gastos relativos com a folha de pagamento dos docentes em regime de dedicação exclusiva (DE); a Relação Aluno Professor (RAP); e a média de formação geral de alunos ingressantes ${ }^{4}$. Em relação a variável do produto (output) foi utilizada a média de formação geral dos estudantes concluintes ${ }^{5}$. Todos esses dados foram coletados de sistemas e sítios oficiais do Governo Federal, quais sejam: Instituto Nacional de Estudos e Pesquisas Educacionais Anísio Teixeira - INEP (INEP, 2015) e Sistema Integrado de Administração de Recursos Humanos - SIAPE (SIAPE, 2015). Demonstraremos no Quadro 1 as variáveis utilizadas (inputs e output) neste estudo para obtenção da avaliação e mensuração da eficiência dos 27 (vinte e sete) cursos de graduação da UnB, nos anos de 2008 a 2010:

Quadro 1 - Variáveis utilizadas para cálculo da eficiência dos cursos da Universidade de Brasília

\begin{tabular}{|l|l|}
\hline \multicolumn{1}{|c|}{ Insumos (Inputs) } & \multicolumn{1}{|c|}{ Produto (Output) } \\
\hline - Média de formação geral dos ingressantes; & \\
- Média salarial do docente (DE); e & - Média de formação geral dos concluintes \\
- Relação "Professor/Aluno" & \\
\hline
\end{tabular}

Fonte: Elaboração própria

Quanto as variáveis de insumo (inputs), temos a destacar:

- A média de formação geral dos alunos ingressante: essa variável foi considerada no estudo devido ao background, ou seja, a "bagagem" que o aluno traz consigo e que influencia no seu rendimento escolar, que pouco se modifica ao longo de quatro anos cursados. Sabe-se que essa variável tem grande influência no resultado, ou seja, na nota de formação geral do concluinte que neste estudo é o produto (output). Os dados dessa variável foram extraídos do Relatório de Cursos do Enade ${ }^{6}$, e estão disponíveis

\footnotetext{
${ }^{3}$ DMU: Decision Making Unit.

${ }^{4}$ Ingressantes: alunos que se encontram no final do primeiro ano do curso.

${ }^{5}$ Concluintes: alunos que estão cursando o último ano do curso.

${ }^{6}$ O Enade, como parte do Sistema Nacional de Avaliação da Educação Superior (Sinaes), tem por objetivo aferir o desempenho dos estudantes em relação aos conteúdos programáticos previstos nas diretrizes curriculares dos respectivos cursos de graduação, às suas habilidades para ajustamento, às exigências decorrentes da evolução do conhecimento e às suas competências para compreender temas exteriores ao âmbito específico de sua
} 
no sítio do Instituto Nacional de Estudos e Pesquisas Educacionais Anísio Teixeira (INEP, 2015).

- A média salarial do docente (DE): esta variável é relativa aos gastos com a folha de pagamento de docentes ativos, ou seja, não sendo considerados, para efeito de cálculos, os docentes por ventura cedidos a outros Órgãos. Os valores relativos à média dos salários dos docentes em regime de dedicação exclusiva (DE) foram extraídos do Relatório Data Warehouse (DW) emitido pelo Sistema Integrado de Administração de Recursos Humanos (SIAPE), que é o sistema oficial do Governo Federal para pagamento dos Servidores Públicos Federais do Poder Executivo vinculados à Universidade de Brasília.

- A Relação Aluno Professor (RAP): representa um indicador calculado pela razão entre a quantidade de docentes DE vinculados aos respectivos departamentos dos cursos avaliados pela quantidade de alunos do respectivo departamento. Essa variável torna-se significativa uma vez que essa relação tem influência direta na qualidade da formação dos alunos. Os dados relativos a esta variável (em relação aos alunos) foram extraídos do Sistema de Graduação (SIGRA/UnB) fornecidos pelo Decanato de Planejamento e Orçamento (DPO/UnB). Já os números de docentes foram extraídos do Data Warehouse (DW/SIAPE), fornecido pelo Decanato de Gestão de Pessoas (DGP/UnB). Vale destacar que o SIAPE contém as informações pessoais, funcionais e financeiras dos servidores da Administração Pública Federal.

Quanto a variável de produto (output), temos a destacar:

- A Média de formação geral dos alunos concluintes, que representa o resultado da nota dos alunos que cursavam o último ano do curso de graduação que realizaram o Enade.

Nas Tabelas a seguir foram colocados os números utilizados para medir a eficiência técnica dos cursos de graduação na UnB, para os anos de 2008 a 2010. Os cursos foram classificados em ordem alfabética, e em seguida, caracterizados com seus respectivos DMUs. A Tabela 3 demonstra todas as variáveis de entrada (inputs) utilizadas com seus respectivos índices e valores. Nas Tabelas 4, 5 e 6, estão descritas cada uma dessas variáveis (inputs) separadamente, e classificadas em ordem crescente. 
Tabela 3 - Relação dos cursos avaliados e as variáveis (inputs) utilizadas

\begin{tabular}{|c|c|c|c|c|c|}
\hline DMU & Cursos Avaliados & Ano & $\begin{array}{c}\text { Relação } \\
\text { Aluno } \\
\text { Professor }\end{array}$ & $\begin{array}{l}\text { Média Salarial } \\
\text { (Docente DE) }\end{array}$ & $\begin{array}{l}\text { Nota Enade } \\
\text { Formação Geral } \\
\text { Ingressante } \\
\text { (média) }\end{array}$ \\
\hline 1 & Administração & 2009 & 0,0307692 & $\mathrm{R} \$ 9.448,05$ & 55,3 \\
\hline 2 & Agronomia & 2010 & 0,1636364 & $\mathrm{R} \$ 11.501,4$ & 46,7 \\
\hline 3 & Arquivologia & 2009 & 0,0745501 & $\mathrm{R} \$ 10.942,00$ & 56,5 \\
\hline 4 & Bach. Ciência da Computação & 2008 & 0,0695876 & $\mathrm{R} \$ 5.884,09$ & 50,1 \\
\hline 5 & Biologia & 2008 & 0,0065147 & $\mathrm{R} \$ 8.249,22$ & 52,4 \\
\hline 6 & Ciências Contábeis & 2009 & 0,0211516 & $\mathrm{R} \$ 7.430,54$ & 59,0 \\
\hline 7 & Design & 2009 & 0,0670391 & $\mathrm{R} \$ 8.394,60$ & 72,3 \\
\hline 8 & Direito & 2009 & 0,0343949 & $\mathrm{R} \$ 9.248,17$ & 67,8 \\
\hline 9 & Enfermagem & 2010 & 0,0402098 & $\mathrm{R} \$ 10.229,00$ & 51,4 \\
\hline 10 & Engenharia Civil & 2008 & 0,0745968 & $\mathrm{R} \$ 7.295,47$ & 57,5 \\
\hline 11 & Estatística & 2009 & 0,0905512 & $\mathrm{R} \$ 9.919,31$ & 47,4 \\
\hline 12 & Farmácia & 2010 & 0,1286174 & $\mathrm{R} \$ 11.530,90$ & 53,7 \\
\hline 13 & Filosofia & 2008 & 0,0460526 & $\mathrm{R} \$ 7.023,36$ & 32,2 \\
\hline 14 & Física & 2008 & 0,0728155 & $\mathrm{R} \$ 7.095,51$ & 48,6 \\
\hline 15 & Geografia & 2008 & 0,025641 & $\mathrm{R} \$ 6.106,91$ & 43,8 \\
\hline 16 & História & 2008 & 0,0349515 & $\mathrm{R} \$ 6.692,00$ & 47,4 \\
\hline 17 & Jornalismo & 2009 & 0,0268097 & $\mathrm{R} \$ 8.952,14$ & 50,3 \\
\hline 18 & Matemática & 2008 & 0,0635155 & $\mathrm{R} \$ 5.996,78$ & 52,0 \\
\hline 19 & Medicina & 2010 & 0,1267327 & $\mathrm{R} \$ 11.550,60$ & 58,6 \\
\hline 20 & Música & 2009 & 0,0571429 & $\mathrm{R} \$ 8.813,41$ & 44,8 \\
\hline 21 & Nutrição & 2010 & 0,0763359 & $\mathrm{R} \$ 10.992,70$ & 50,4 \\
\hline 22 & Odontologia & 2010 & 0,1369863 & $\mathrm{R} \$ 10.730,40$ & 54,2 \\
\hline 23 & Publicidade e Propaganda & 2009 & 0,0601504 & $\mathrm{R} \$ 9.507,69$ & 42,1 \\
\hline 24 & Química & 2008 & 0,0433763 & $\mathrm{R} \$ 6.121,26$ & 51,1 \\
\hline 25 & Relações Internacionais & 2009 & 0,0328947 & $\mathrm{R} \$ 13.721,70$ & 75,9 \\
\hline 26 & Serviço Social & 2010 & 0,0822368 & $\mathrm{R} \$ 9.010,71$ & 5,90 \\
\hline 27 & Teatro & 2009 & 0,0673401 & $\mathrm{R} \$ 9.013,16$ & 40,6 \\
\hline
\end{tabular}

Fonte: Inep (2015), SIGRA (2015) e SIAPE (2015).

Os indicadores relativos à RAP são os resultados dos dados obtidos a partir das informações de números de professores com jornada de dedicação exclusiva (DE) e o número total de alunos. A Tabela 4, a seguir, demonstrará de forma detalhada os números utilizados e que geraram o referido indicador, classificados em ordem crescente. Ressaltamos que os cursos que demonstraram melhor percentual da RAP são: Agronomia; Odontologia; Farmácia e Medicina. Já o curso de Biologia apresentou um pequeno índice, uma vez que é baixo o número de docentes em relação a quantidade de alunos. 
Tabela 4 - Valores usados para cálculo da Relação Aluno Professor (RAP)

\begin{tabular}{|c|c|c|c|c|c|c|}
\hline DMU & Cursos Avaliados & Ano & $\begin{array}{c}\mathbf{N}^{\mathbf{o}} \\
\text { Docentes } \\
\text { Dedicação } \\
\text { Exclusiva }\end{array}$ & $\begin{array}{c}\mathbf{N}^{\mathbf{o}} \\
\text { Alunos }\end{array}$ & $\mathbf{R A P}$ & $\%$ RAP \\
\hline 2 & Agronomia & 2010 & 72 & 440 & 0,1636364 & $16,36 \%$ \\
\hline 22 & Odontologia & 2010 & 30 & 219 & 0,1369863 & $13,70 \%$ \\
\hline 12 & Farmácia & 2010 & 40 & 311 & 0,1286174 & $12,86 \%$ \\
\hline 19 & Medicina & 2010 & 64 & 505 & 0,1267327 & $12,67 \%$ \\
\hline 11 & Estatística & 2009 & 23 & 254 & 0,0905512 & $9,06 \%$ \\
\hline 26 & Serviço Social & 2010 & 25 & 304 & 0,0822368 & $8,22 \%$ \\
\hline 21 & Nutrição & 2010 & 20 & 262 & 0,0763359 & $7,63 \%$ \\
\hline 10 & Engenharia Civil & 2008 & 37 & 496 & 0,0745968 & $7,46 \%$ \\
\hline 3 & Arquivologia & 2009 & 29 & 389 & 0,0745501 & $7,46 \%$ \\
\hline \multirow{2}{*}{$\begin{array}{c}14 \\
4\end{array}$} & Física & 2008 & 45 & 618 & 0,0728155 & $7,28 \%$ \\
\hline & Computação & 2008 & 27 & 388 & 0,0695876 & $6,96 \%$ \\
\hline 27 & Teatro & 2009 & 20 & 297 & 0,0673401 & $6,73 \%$ \\
\hline 7 & Design & 2009 & 24 & 358 & 0,0670391 & $6,70 \%$ \\
\hline 18 & Matemática & 2008 & 43 & 677 & 0,0635155 & $6,35 \%$ \\
\hline 23 & Publicidade e Propaganda & 2009 & 16 & 266 & 0,0601504 & $6,02 \%$ \\
\hline 20 & Música & 2009 & 24 & 420 & 0,0571429 & $5,71 \%$ \\
\hline 13 & Filosofia & 2008 & 14 & 304 & 0,0460526 & $4,61 \%$ \\
\hline 24 & Química & 2008 & 37 & 853 & 0,0433763 & $4,34 \%$ \\
\hline 9 & Enfermagem & 2010 & 23 & 572 & 0,0402098 & $4,02 \%$ \\
\hline 16 & História & 2008 & 18 & 515 & 0,0349515 & $3,50 \%$ \\
\hline 8 & Direito & 2009 & 27 & 785 & 0,0343949 & $3,44 \%$ \\
\hline 25 & Relações Internacionais & 2009 & 15 & 456 & 0,0328947 & $3,29 \%$ \\
\hline 1 & Administração & 2009 & 36 & 1170 & 0,0307692 & $3,08 \%$ \\
\hline 17 & Jornalismo & 2009 & 10 & 373 & 0,0268097 & $2,68 \%$ \\
\hline 15 & Geografia & 2008 & 14 & 546 & 0,025641 & $2,56 \%$ \\
\hline 6 & Ciências Contábeis & 2009 & 18 & 851 & 0,0211516 & $2,12 \%$ \\
\hline 5 & Biologia & 2008 & 8 & 1228 & 0,0065147 & $0,65 \%$ \\
\hline
\end{tabular}

A Tabela 5, a seguir, demonstra a classificação em ordem crescente da variável (input) relativa a média salarial paga aos docentes em regime de dedicação exclusiva. $O$ curso de Relações Internacionais, apresentou o maior gasto, seguidos dos cursos de Medicina, Farmácia e Agronomia que apresentaram uma média de gasto de 11,5 mil. Ressalta-se que o curso de Medicina, apresentou o segundo maior salário médio para docente, e está entre os quatro primeiros cursos que tem uma boa Relação Aluno Professor (RAP). O curso de Agronomia, quarto curso com maior gasto com salário de docente, foi o curso com melhor Relação Aluno Professor (RAP). O curso de Farmácia, o terceiro curso com maior salário 
médio, também foi o terceiro no ranking no indicador Relação Aluno Professor, conforme se verifica na Tabela 4.

Tabela 5 - Média salarial (mensal) dos docentes Dedicação Exclusiva

\begin{tabular}{|c|c|c|c|}
\hline DMU & Cursos Avaliados & Ano & $\begin{array}{l}\text { Média Salarial } \\
\text { (Docente DE) }\end{array}$ \\
\hline 25 & Relações Internacionais & 2009 & $\mathrm{R} \$ 13.721,70$ \\
\hline 19 & Medicina & 2010 & $\mathrm{R} \$ 11.550,60$ \\
\hline 12 & Farmácia & 2010 & $\mathrm{R} \$ 11.530,90$ \\
\hline 2 & Agronomia & 2010 & $\mathrm{R} \$ 11.501,4$ \\
\hline 21 & Nutrição & 2010 & $\mathrm{R} \$ 10.992,70$ \\
\hline 3 & Arquivologia & 2009 & $\mathrm{R} \$ 10.942,00$ \\
\hline 22 & Odontologia & 2010 & $\mathrm{R} \$ 10.730,40$ \\
\hline 9 & Enfermagem & 2010 & $\mathrm{R} \$ 10.229,00$ \\
\hline 11 & Estatística & 2009 & $\mathrm{R} \$ 9.919,31$ \\
\hline 23 & Publicidade e propaganda & 2009 & $\mathrm{R} \$ 9.507,69$ \\
\hline 1 & Administração & 2009 & $\mathrm{R} \$ 9.448,05$ \\
\hline 8 & Direito & 2009 & $\mathrm{R} \$ 9.248,17$ \\
\hline 27 & Teatro & 2009 & $\mathrm{R} \$ 9.013,16$ \\
\hline 26 & Serviço Social & 2010 & $\mathrm{R} \$ 9.010,71$ \\
\hline 17 & Jornalismo & 2009 & $\mathrm{R} \$ 8.952,14$ \\
\hline 20 & Música & 2009 & $\mathrm{R} \$ 8.813,41$ \\
\hline 7 & Design & 2009 & $\mathrm{R} \$ 8.394,60$ \\
\hline 5 & Biologia & 2008 & $\mathrm{R} \$ 8.249,22$ \\
\hline 6 & Ciências contábeis & 2009 & $\mathrm{R} \$ 7.430,54$ \\
\hline 10 & Engenharia Civil & 2008 & $\mathrm{R} \$ 7.295,47$ \\
\hline 14 & Física & 2008 & $\mathrm{R} \$ 7.095,51$ \\
\hline 13 & Filosofia & 2008 & $\mathrm{R} \$ 7.023,36$ \\
\hline 16 & História & 2008 & $\mathrm{R} \$ 6.692,00$ \\
\hline 24 & Química & 2008 & $\mathrm{R} \$ 6.121,26$ \\
\hline 15 & Geografia & 2008 & $\mathrm{R} \$ 6.106,91$ \\
\hline 18 & Matemática & 2008 & $\mathrm{R} \$ 5.996,78$ \\
\hline 4 & Bacharel em Ciência da computação & 2008 & $\mathrm{R} \$ 5.884,09$ \\
\hline
\end{tabular}

Na Tabela 6, a seguir, demostra a variável (input) relativa à nota média de formação geral dos ingressantes que realizaram o Enade. Essa variável foi considerada neste estudo pois reflete diretamente no produto (output) devido ao background dos alunos. Vejamos a classificação dos cursos em ordem crescente. 
Tabela 6 - Nota (média) de formação geral dos alunos ingressantes do Exame Nacional de Desempenho de Estudantes (Enade)

\begin{tabular}{lllc}
\hline DMU & Cursos Avaliados & Ano & Nota Enade \\
\hline $\mathbf{2 5}$ & Relações Internacionais & 2009 & 75,9 \\
$\mathbf{7}$ & Design & 2009 & 72,3 \\
$\mathbf{8}$ & Direito & 2009 & 67,8 \\
$\mathbf{6}$ & Ciências contábeis & 2009 & 59,0 \\
$\mathbf{1 9}$ & Medicina & 2010 & 58,6 \\
$\mathbf{1 0}$ & Engenharia Civil & 2008 & 57,5 \\
$\mathbf{3}$ & Arquivologia & 2009 & 56,5 \\
$\mathbf{1}$ & Administração & 2009 & 55,3 \\
$\mathbf{2 2}$ & Odontologia & 2010 & 54,2 \\
$\mathbf{1 2}$ & Farmácia & 2010 & 53,7 \\
$\mathbf{5}$ & Biologia & 2008 & 52,4 \\
$\mathbf{1 8}$ & Matemática & 2008 & 52,0 \\
$\mathbf{9}$ & Enfermagem & 2010 & 51,4 \\
$\mathbf{2 4}$ & Química & 2008 & 51,1 \\
$\mathbf{2 1}$ & Nutrição & 2010 & 50,4 \\
$\mathbf{1 7}$ & Jornalismo & 2009 & 50,3 \\
$\mathbf{4}$ & Bacharelado em Ciência da computação & 2008 & 50,1 \\
$\mathbf{1 4}$ & Física & 2008 & 48,6 \\
$\mathbf{1 1}$ & Estatística & 2009 & 47,4 \\
$\mathbf{1 6}$ & História & 2008 & 47,4 \\
$\mathbf{2}$ & Agronomia & 2010 & 46,7 \\
$\mathbf{2 0}$ & Música & 2009 & 44,8 \\
$\mathbf{1 5}$ & Geografia & 2008 & 43,8 \\
$\mathbf{2 3}$ & Publicidade e propaganda & 42,1 \\
$\mathbf{2 7}$ & Teatro & 2009 & 40,6 \\
$\mathbf{1 3}$ & Filosofia & 2009 & 32,2 \\
$\mathbf{2 6}$ & Serviço Social & 2008 & 5,90 \\
\hline $\mathbf{7 0}$ & (2015). & \\
\hline
\end{tabular}

Fonte: Inep (2015).

Observamos que os alunos (ingressantes) do curso de Relações Internacionais foram o que obtiveram a maior nota de formação geral do Enade. Seguidos dos alunos dos 8 (oito) cursos: Design; Direito; Ciências Contábeis; Medicina; Engenharia Civil; Arquivologia; Administração e Odontologia. O curso de Agronomia, $1^{a}$ posição na Relação Aluno Professor apresenta-se na $21^{\text {a }}$ posição em relação as notas dos alunos ingressantes. O curso de Direito, apesar de ser classificado na $21^{\mathrm{a}}$ posição com relação a RAP, os seus alunos (ingressantes) apresentaram boa nota no Enade, posicionada em $3^{\text {a }}$ posição do ranking. Os alunos ingressantes do curso de Serviço Social apresentaram a nota 5,9, mais baixa no Enade. Enquanto o $1^{\circ}$ lugar no ranking é o curso de Relações Internacionais, cujo alunos obtiveram a melhor nota 75,9. Verificamos que o curso de Serviço Social está na $6^{\text {a }}$ posição em Relação 
Aluno Professor e na $14^{\mathrm{a}}$ posição em relação ao gasto com pagamento de docentes. O curso de Filosofia apresentou a segunda menor nota dos ingressantes no Enade $(32,2)$.

Após demonstrados detalhadamente cada valor, número e índices utilizados nas variáveis de entrada (inputs), faremos, a seguir, conforme dados da Tabela 7 uma classificação dos cursos avaliados que apresentaram as maiores notas médias na formação geral dos concluintes.

Tabela 7 - Nota (média) de formação geral dos alunos concluintes do Exame Nacional de Desempenho de Estudantes (Enade)

\begin{tabular}{|c|c|c|c|}
\hline DMU & Cursos Avaliados & Ano & Nota Enade \\
\hline 25 & Relações Internacionais & 2009 & 74,1 \\
\hline 7 & Design & 2009 & 72,1 \\
\hline 8 & Direito & 2009 & 65,8 \\
\hline 19 & Medicina & 2010 & 65,0 \\
\hline 1 & Administração & 2009 & 62,3 \\
\hline 6 & Ciências Contábeis & 2009 & 61,6 \\
\hline 5 & Biologia & 2008 & 60,3 \\
\hline 10 & Engenharia Civil & 2008 & 57,2 \\
\hline 22 & Odontologia & 2010 & 56,0 \\
\hline 11 & Estatística & 2009 & 55,1 \\
\hline 4 & $\begin{array}{l}\text { Bacharelado em Ciência da } \\
\text { Computação }\end{array}$ & 2008 & 54,9 \\
\hline 21 & Nutrição & 2010 & 53,7 \\
\hline 24 & Química & 2008 & 53,1 \\
\hline 16 & História & 2008 & 53,0 \\
\hline 12 & Farmácia & 2010 & 53,0 \\
\hline 2 & Agronomia & 2010 & 50,8 \\
\hline 14 & Física & 2008 & 48,3 \\
\hline 27 & Teatro & 2009 & 47,2 \\
\hline 18 & Matemática & 2008 & 46,8 \\
\hline 3 & Arquivologia & 2009 & 45,9 \\
\hline 20 & Música & 2009 & 44,9 \\
\hline 17 & Jornalismo & 2009 & 43,1 \\
\hline 13 & Filosofia & 2008 & 42,3 \\
\hline 23 & Publicidade e Propaganda & 2009 & 41,1 \\
\hline 15 & Geografia & 2008 & 35,6 \\
\hline 9 & Enfermagem & 2010 & 9,90 \\
\hline 26 & Serviço Social & 2010 & 7,20 \\
\hline
\end{tabular}

Fonte: Inep (2015). 
Os resultados apresentados na Tabela 7, acima, referem-se a nota média dos alunos concluintes que neste estudo representa o produto (output). Ao analisar esta Tabela, verificamos que as classificações dos cursos não foram muito diferentes das notas médias de formação geral dos ingressantes, o que reforça a teoria do background. Entretanto, houve discrepância nas notas dos alunos de alguns cursos, por exemplo na Arquivologia, $7^{\mathrm{a}}$ posição na classificação de notas dos alunos ingressantes, caiu para $20^{\mathrm{a}}$ posição na nota dos alunos concluintes. Assim como o curso de Farmácia, que obteve a $10^{\mathrm{a}}$ posição relativa as notas dos alunos ingressantes e caiu para $15^{\mathrm{a}}$ posição. Já o curso de Serviço Social, manteve-se com as menores notas de formação geral de alunos concluintes $(7,2)$ e ingressantes $(5,9)$.

\subsection{Métodos utilizados para mensurar a eficiência}

Para medir a eficiência de empreendimentos alguns trabalhos em economia fazem uso de regressão por mínimos quadrados ordinários, e suas variantes, uma vez que traça o melhor ajuste dos dados, ou seja, é uma função de médias (COELLI, 1995). Entretanto, há outras possibilidades para mensurar a eficiência de unidades produtivas, por meio de fronteiras de produção. Estimar fronteiras de produção tem as seguintes vantagens, conforme Gomes et al. (2001, p. 127):

Reflete a tecnologia usada, já que a estimativa de uma fronteira de produção é influenciada pelas unidades de melhor desempenho dentro da amostra de unidades analisadas, enquanto que as funções de médias fornecem a forma da tecnologia de uma unidade média. A função de produção representa as melhores práticas e, assim, as eficiências das unidades podem ser medidas.

Para Lovell e Schmidt (1993) a eficiência técnica é um critério que permite comparar o desempenho de unidades de produção pertencentes a ambientes institucionais diferentes, ou seja, de instituições de diferentes naturezas. Já para Belloni (2000), a eficiência na produção pode ser analisada sob dois pontos de vista: eficiência produtiva e eficiência alocativa. A primeira (eficiência produtiva) é a habilidade de evitar desperdício, ou seja, produzindo tantos resultados quanto os recursos utilizados permitirem ou utilizando o mínimo possível de recursos para aquela produção. O objetivo é obter ganhos de produtividade eliminando as fontes de ineficiência. O segundo ponto de vista (eficiência alocativa) se refere a habilidade de combinar recursos e resultados em proporções ótimas dados os preços vigentes. A inexistência de qualquer tipo de relação de preços entre os resultados da atividade acadêmica inviabiliza a avaliação dessa eficiência.

Segundo Färe, Grosskopf e Lovell (1995, p. 738), a eficiência produtiva é definida: 
[...] um produtor é eficiente quanto um aumento na produção de qualquer dos resultados exige uma redução em pelo menos um outro resultado ou um acréscimo no consumo de pelo menos um dos recursos, e, quando a redução do consumo de qualquer recurso exige um acréscimo no consumo de pelo menos um outro recurso ou a redução na produção de pelo menos um dos resultados.

Penã (2008) conceitua eficiência como a combinação ótima e de métodos necessários de insumos (inputs) no processo produtivo de modo que gerem o máximo de produto (output). Para o referido autor, a eficiência visa assegurar a otimização da utilização dos recursos disponíveis e divide-se em eficiência técnica e econômica. Do ponto de vista técnico ou tecnológico, entende-se quando se emprega o menor nível de insumos possível para produzir um determinado nível de produto. Já do ponto de vista econômico, é quando se produz mais com menos ou o mesmo custo. Ressalta-se que a produção para ser economicamente eficiente requer máxima eficiência técnica.

Após essa contextualização sobre o conceito e os tipos de eficiência, citaremos brevemente alguns métodos utilizados para mensuração da fronteira de produção. Os Métodos não-paramétricos podem ser efetuados utilizando: Free Disposable Hull (FDH) e/ou Data Envelopment Analysis (DEA). Já quanto aos métodos paramétricos (econométricos), citamos a Fronteira de Produção Estocástica (FPE).

O Free Disposable Hull (FDH), foi proposto inicialmente por Deprins, Simar e Tulkens (1984). O método é não-paramétrico, que por vezes é completado com análise de regressão, conforme estudos de Ray (1991) e Ruggiero (1996). Outra característica do FDH é que ele requer uma única hipótese para que exista uma fronteira de produção e que seja contínua, qual seja, a de que insumos e produtos possam ser livremente descartados não sendo necessário que o conjunto de possibilidades de produção seja convexo, conforme Zoghbi et al. (2009, p. 795). No método FDH não é preciso assumir uma fronteira de produção convexa. Na existência de "n" cursos na amostra, "m" produtos produzidos por esses cursos e "k" insumos utilizados na produção dos “m” produtos, temos:

$$
y_{i}=F\left(x_{i}\right)
$$

Em que:

“ $y$ ” é o vetor de produtos (output) e " $x$ ” é o vetor de insumos (input)

O método DEA, que também é um modelo não-paramétrico, supõe apenas a concavidade da função de produção e ignora o ruído (erro) contido no dado. Para Banker (1993) a produtividade medida por esse método é um estimador de máxima verossimilhança. 
O referido modelo surgiu com Farrel (1957), e tornou-se popular na literatura após Charnes, Cooper e Rhodes (1978) sendo colocada como um problema de otimização e também por terem-no utilizado para avaliações de problemas concretos. Ressalta-se que o princípio da metodologia DEA é baseado na definição física de eficiência, segundo a qual a eficiência é dada pela relação entre múltiplos insumos utilizados e múltiplos produtos gerados. Dessa forma, quanto maior for a produção de uma unidade para uma dada quantidade de insumos, ou alternativamente, quanto menor for a quantidade de insumos utilizada para uma determinada quantidade de produto, maior será a eficiência desta unidade. O DEA mensura a eficiência das Unidades Tomadoras de Decisão chamadas de DMUs, que as comparando entre si obtém-se um indicador de eficiência relativa.

Essa metodologia utiliza DMUs como as melhores práticas observadas construindo com base nelas uma fronteira de produção empírica denominada fronteira eficiente. O DEA é uma técnica que constrói as fronteiras de produção usando programação linear. Para demonstrar citaremos Zoghbi et. al. (2009), supondo que existam "n" cursos na amostra para "m" produtos produzidos e " $\mathrm{k}$ " insumos. Assim, para todos cursos existirá um vetor coluna de produtos $\left(y_{i}\right)$ e um vetor coluna de insumos $\left(\boldsymbol{x}_{i}\right)$. Complementa-se com existência de uma matriz $\boldsymbol{X}(\mathrm{k} \times \mathrm{n})$ de insumos e uma matriz $\boldsymbol{Y}(\mathrm{m} \times \mathrm{n})$ de produto, apresenta-se então um problema matemático de programação linear da seguinte forma:

$$
\begin{gathered}
M I N_{\Theta \lambda} \theta \\
\text { Sujeito a: } \\
-y_{i}+Y \lambda \geq 0 \\
\theta_{x i}+X \lambda \geq 0 \\
n_{1}^{\prime} \lambda=1 \\
\lambda \geq 0
\end{gathered}
$$

$\theta$ é um escalar que satisfaz $(\theta \leq 1)$ medindo a eficiência técnica do curso $\left(x_{i}, y_{i}\right)$, representa a medida da distância entre o curso avaliado e a fronteira de eficiência técnica. Se $\theta$ $<1$, o curso estará dentro da fronteira e, portanto, será ineficiente. Se $\theta=1$, o curso estará na fronteira e, portanto, será eficiente. $\mathrm{O}$ vetor $\lambda$ é um vetor $\left(\begin{array}{lll}n & x & 1\end{array}\right)$ de constantes com os pesos usados para computar a alocação ineficiente dos cursos se eles forem ineficientes. O $n_{1}{ }_{1}$ é um vetor dimensional de uns $n_{1}{ }_{1} \lambda=1$ impõe a convexidade da fronteira. 
Por fim, citaremos a Fronteira de Produção Estocástica (FPE) que é utilizada para estimação da eficiência na econometria, ou seja, com equações paramétricas. Esta metodologia de fronteira estocástica foi aplicada na Ásia por Estache e Martins (2002) para determinar a eficiência regional de companhias de água por meio da função custo. Já Franco e Fortuna (2013) utilizaram esse método para estimar a eficiência técnica de hospitais portugueses. Ohira e Shirota (2005) fizeram estimativas para mensurar a eficiência das empresas do setor de saneamento básico no estado de São Paulo. Esse modelo de fronteira de produção determinística ou estocástica mede a produtividade técnica de processos com múltiplos produtos e fatores, e a produtividade econômica quando pelo menos um dos preços não é conhecido. Salienta-se que esse modelo considera o ruído (erro), mas depende da especificação funcional da função de produção. Cabe destacar que FPE busca representar a produção máxima que se pode obter dada uma certa quantidade de recursos (KUMBHAKAR e LOVELL, 2000). No entanto, surgem dificuldades de medição de resultados no processo educativo, uma vez que a multiplicidade de fatores que influenciam a aprendizagem dos alunos, tais como: características dos professores; a interação com os colegas ou as capacidades inatas são de difícil incorporação num modelo empírico, conforme citam Pereira e Moreira (2007).

Segundo Zoghbi, Rocha e Mattos (2012), a FPE traz a possibilidade de fazer a decomposição de resíduo em dois componentes, quais sejam: i) relativo à ineficiência e ii) choque aleatório. Citamos Zoghbi et al. (2009, p. 795):

$$
\begin{gathered}
\ln y_{i}=\beta_{0}+f\left(\beta_{k}, x_{i}^{k}\right)+v_{i}-u_{i} \\
\text { Onde: } \\
i=1, \ldots \mathrm{I} ; \mathrm{k}=1, \ldots, \mathrm{n},
\end{gathered}
$$

Em que $\ln _{i}$ é o logaritmo da quantidade produzida pela firma $i ; \beta_{0}$ é o intercepto da equação; $f\left(\beta_{k}, x_{i}^{k}\right)$ é a forma funcional adequada. $\beta_{k}$ é o vetor de coeficientes tecnológicos; $x_{i}^{k}$ é o vetor de insumo utilizado na produção pela firma $i ; v_{i}$ é o choque aleatório não correlacionado com $x_{i}^{k}$, ou seja, por isso considerado como aleatório e $u_{\bar{i}}$, com distribuição $N\left(0, \sigma_{v}^{2}\right)$ e $u_{i}$ é o termo de ineficiência não negativo da firma $i$ também não correlacionado $\operatorname{com} x_{i}^{k}$

Outra forma de descrição da FPE, feita por Moreira e Fonseca (2005), demonstraremos a seguir: 


$$
\begin{gathered}
y=\boldsymbol{x} \boldsymbol{\beta}+\boldsymbol{e} \\
\text { Onde: } e=v-u \\
v \sim N\left(0, \sigma^{2}\right) \text { e } \quad u \sim N^{0}\left(0, \tau^{2}\right)
\end{gathered}
$$

Onde a medida de produtividade (-u) é identificada admitindo que tenha uma distribuição assimétrica, no caso, que tenha distribuição normal truncada no 0. Segundo os autores, esse modelo é vulnerável: i) ao tamanho da amostra, uma vez que para amostras pequenas não é possível distinguir a distribuição do ruído da distribuição da produtividade; ii) à proporção entre a variância da produtividade do ruído e da produtividade; e iii) ao erro de especificação da forma funcional.

Ressalta-se que tanto o modelo DEA quanto o modelo FPE propiciam estimativas de produtividade técnica ou econômica possibilitando muitas aplicações e servem para descrever de forma comparativa o estado de um segmento de atividades, ou ainda, se admite que exista um conjunto de agentes ou unidades de decisão que utilizam recursos para produzir. O agente mais eficiente é o que utiliza menor quantidade de fatores por unidade de produto, ou viceversa, que produza a maior quantidade de produtos dada uma dotação de recursos (CUBBIN e TZANIDAKIS, 1998)

No entanto, a metodologia escolhida neste estudo foi o DEA, por ser um modelo flexível, torna-se vantajoso, uma vez que esse modelo assume poucas hipóteses sobre o comportamento das variáveis e por isso não implicam nenhuma forma funcional a priori para a fronteira de educação, conforme descrevem Delgado e Machado (2007). Ressalta-se, ainda, que essa metodologia capta a melhor prática existente da organização produtiva e cria um referencial para as áreas analisadas. Para Casado e Sousa (2007, p. 7):

\begin{abstract}
A técnica DEA verifica se cada unidade opera de maneira adequada ou não, relativamente a um elenco específico de recursos utilizados e de recursos obtidos, em comparação com unidades consideradas similares por seus administradores, sem a necessidade de conhecer a priori qualquer relação de importância (pesos) entre as variáveis consideradas.
\end{abstract}

Essa característica de agregar variáveis e indicadores de avaliação, sem exigir que sejam conhecidos pesos relativos entre eles, credencia essa técnica do DEA para utilização das informações coletadas na Universidade de Brasília para realização deste trabalho. 


\subsection{Análise Envoltória de Dados (DEA)}

Neste trabalho foi utilizado o método de Análise Envoltória de Dados (DEA) como ferramenta para análise da fronteira eficiente de 27 (vinte e sete) cursos de graduação da UnB, no período de 2008 a 2010.

Essa técnica construída por Farrel (1957) utiliza uma abordagem não-paramétrica de programação matemática, ou seja, mensura a eficiência por Programação Linear (PL) ${ }^{7}$ para estimação da eficiência relativa de unidades produtivas ou decisórias (DMUs). O DEA parte do pressuposto de que existe certo número de DMUs que convertem insumos (inputs) em produtos (outputs) ou resultados (outcomes), conforme Boueri (2015). Via de regra, se tem inúmeras maneiras de distribuir os recursos escassos entre as diversas atividades em estudo, bastando para com isso que essas distribuições estejam coerentes com as restrições do modelo. Contudo, o que de fato se busca num problema de Progamação Linear é a função objetivo, ou seja, a maximização do lucro (produção) ou a minimização do custo (insumos), o que nada mais é que a "solução ótima".

Sabe-se que a eficiência calculada pelo DEA é uma eficiência relativa, baseada em observações reais. As DMUs têm seus desempenhos medidos por meio da comparação de seus resultados e dos seus insumos com os resultados e insumos de outras DMUs da amostra. As DMUs consideradas eficientes determinam a fronteira de eficiência e possuem escore igual a 1 (um) ou $100 \%$ (cem por cento). Esse método possui como uma importante característica a habilidade em manipular, efetivamente, a natureza multidimensional de insumos e produtos nos processos de produção.

Com relação às variáveis consideradas no processo produtivo (insumos e produtos), estas devem operar na mesma unidade de medida em todas DMUs (LINS e MEZA, 2000). Os principais objetivos da DEA podem ser resumidos conforme GOMES et al. (2001, p. 127):

\footnotetext{
- comparar um número de DMUs que realizam tarefas similares e se diferenciam nas quantidades de inputs que consumem e de outputs que produzem;

- identificar as DMUs eficientes, medir e localizar a ineficiência e estimar uma função de produção linear por partes (piece-wise linear frontier), que fornece o benchmark (referência) para as DMUs ineficientes. Ao identificar as origens e quantidades de ineficiência relativas de cada uma das DMUs, é possível analisar qualquer de suas dimensões relativas a entradas e/ou saídas. A fronteira de eficiência compreende o conjunto de DMUs Pareto Eficientes;
}

\footnotetext{
${ }^{7}$ A Programação Linear (PL) é uma das técnicas de pesquisa operacional das mais utilizadas para resolução de problemas de otimização, pois busca a distribuição eficiente de recursos limitados para atender a um determinado objetivo, em geral, maximizando lucros (produção) ou minimizando os custos (insumos). Nessa técnica é necessário que se defina quais as atividades que consomem recursos e em que proporções são consumidos, essas informações representam "Restrições do Modelo".
} 
- determinar a eficiência relativa das DMUs, contemplando cada uma, relativamente a todas as outras que compõem o grupo a ser estudado. Assim, sob determinadas condições, DEA pode ser usado na problemática da ordenação como ferramenta multicrédito de apoio a decisão;

- subsidiar estratégias de produção que maximizem a eficiência das DMUs avaliadas, corrigindo as ineficientes através de determinação de alvos;

- estabelecer taxas de substituição entre as entradas, entre as saídas e entre entradas e saídas, permitindo a tomada de decisões gerenciais. O estabelecimento dessas taxas de substituição nem sempre tem solução única;

- considerar a possibilidade de os outliers não representarem apenas desvios em relação ao comportamento "médio", mas possíveis benchmarks a serem analisados pelas demais DMUs. Os outliers podem representar as melhores práticas dentro do universo investigado (...);

No entanto, segundo Moreira e Fonseca (2005, p. 4), o método DEA possui algumas características de vulnerabilidade, quais sejam:

i) a não utilização de informações dos determinantes da produtividade quando conhecidos; ii) a magnitude relativa do ruído; iii) a forma da função de produção, pois para retornos variáveis de escala tende a considerar na fronteira uma proporção maior dos agentes, reduzindo a sua capacidade de distinguir entre os agentes; e $i v$ ) a existência de ponto espúrio. Ora, mesmo apresentando tais vulnerabilidades, o DEA não exige uma forma funcional da função de produção o que o torna viável, pois não causa na estimação o problema de má-especificação do modelo.

O DEA possui dois modelos, um com retornos constantes de escala (CCR) e outro com retornos variáveis de escala (BCC). Segundo Lins e Meza (2000), os pesquisadores americanos Charnes, Cooper e Rhodes (1978) introduziram o modelo DEA-CCR ${ }^{8}$ que constrói uma superfície linear por partes sobre os dados mantendo retornos de escala constante. Esse modelo determina, graficamente, uma fronteira CRS (Constant Returns to Scale), indicando que inputs e outputs obtêm crescimentos proporcionais. Inicialmente, orientado à entrada (input), isto é, qualquer variação nas entradas (inputs) produz variação proporcional nas saídas (outputs), conforme Casado e Souza (2007). Além disso, esse modelo DEA-CCR adiciona uma restrição (a de convexidade).

Segundo Boueri (2015, p. 280), a ideia desse modelo é deixar a própria amostra escolher os pesos para cada unidade. Para o referido autor, no modelo DEA-CCR, segundo o teorema da dualidade da programação linear (sob determinadas condições) uma maximização de uma função objetivo linear sujeita a restrições também lineares pode ser expressa como um problema de minimização de outra função linear. O modelo dual em relação à forma multiplicadora é denominado forma envelopada, e sua ótica para insumos, pode ser expressa:

\section{Min: $\theta_{i}$}

$$
\left\{\theta, \lambda_{1}, \lambda_{2}, \ldots, \lambda_{n}\right\}
$$

\footnotetext{
${ }^{8}$ DEA-CCR, acrônico que reflete as iniciais dos sobrenomes dos pesquisadores Charnes, Cooper e Rhodes.
} 


$$
\begin{aligned}
& \text { Sujeito a: } \\
& \theta_{i} x_{1 i}-\lambda_{1} x_{11}-\lambda_{2} x_{12}-\ldots-\lambda_{n} x_{1 n} \geq 0 \\
& \theta_{i} x_{2 i}-\lambda_{1} x_{21}-\lambda_{2} x_{22}-\ldots-\lambda_{n} x_{2 n} \geq 0 \\
& \theta_{i} x_{m i}-\lambda_{1} x_{m 1}-\lambda_{2} x_{m 2}-\ldots-\lambda_{n} x_{m n n} \geq 0 \\
& -q_{1 i}+\lambda_{1} q_{11}+\lambda_{2} q_{12}+\ldots+\lambda_{n} q_{1 n} \geq 0 \\
& -q_{2 \mathrm{i}}+\lambda_{1} q_{21}+\lambda_{2} q_{22}+\ldots+\lambda_{n 1} q_{2 n} \geq 0 \\
& -q_{s i}+\lambda_{1} q_{s 1}+\lambda_{2} q_{s 2}+\ldots+\lambda_{n} q_{s n} \geq 0 \\
& \lambda_{1}, \lambda_{2}, \ldots, \lambda_{n} \geq 0
\end{aligned}
$$

Ou, ainda, em notação matricial:

\section{$\operatorname{Min}: \theta_{i}$}

$\{\theta, \lambda\}$

Sujeito a:

$$
\begin{gathered}
\theta_{\mathrm{i}} \boldsymbol{x}_{i}-X \lambda \geq \mathbf{0}_{m} \\
Q \lambda-\boldsymbol{q}_{\mathrm{i}} \geq \mathbf{0}_{s} \\
\lambda \geq \mathbf{0}_{n}
\end{gathered}
$$

Onde $\theta_{i}$ é o escore de eficiência da $D M U i, \boldsymbol{x}_{\boldsymbol{i}}$ é o vetor (m x 1) de insumos utilizados pela $D M U i, \boldsymbol{q}_{i}$ é o vetor (s x 1 ) de produtos gerados pela $D M U i, \lambda$, é o vetor (n x1) de pesos para combinações lineares, $\boldsymbol{X}$ é uma matriz ( $\mathrm{m} \mathrm{x} \mathrm{n)}$ ) formada pelos vetores de insumos transpostos de todas as DMUs da amostra, $\boldsymbol{Q}$ é uma matriz (s x n) formada pelos vetores transpostos de produtos de todas as DMUs da amostra e $\mathbf{0}_{j}$ é o vetor nulo com a dimensão $j$ apropriada. Ressalta-se que nessa formulação, segundo o autor, o vetor $\boldsymbol{\lambda}$ contém os pesos para fazer as melhores combinações lineares com os vetores de insumos e de produtos de todas as DMUs da amostra. O objetivo é encontrar o menor $\theta$ possível, ou seja, promover a maior redução proporcional possível na utilização de insumos da $D M U i$, mas de forma que ela ainda possa ser expressa como uma combinação linear dos vetores das outras DMUs. 
$\mathrm{Na}$ ótica do produto, segundo o mesmo autor, o problema na forma envelopada busca a maior expansão proporcional possível dos produtos de determinada DMUs até que eles atinjam a maior combinação linear possível dos vetores de produtos existentes na amostra, conforme demonstra matematicamente:

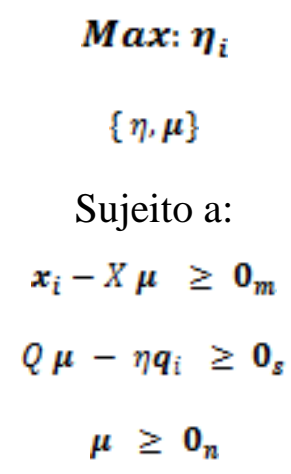

No caso da DMUi estar sobre a fronteira de eficiência, o seu conjunto de pesos para melhor combinação linear será um vetor todo composto por zeros, exceto no elemento correspondente à própria $D M U i$, o qual será igual a 1 (um). Aqui o autor reforça que a melhor combinação linear que se pode obter com os vetores da amostra e que é proporcional aos vetores da DMUi são os próprios vetores dessa DMU.

Sobre o DEA-CCR, citamos ainda o que afirma Biondi Neto (2001, p. 51):

\begin{abstract}
A característica essencial do modelo CCR é a redução de múltiplos produtos e múltiplos insumos (para cada DMU) para um único produto 'virtual'. Para uma DMU, a razão entre esse produto virtual e o insumo virtual fornece uma medida de eficiência que é função dos multiplicadores. Essa proporção, que será maximizada, forma a função-objetivo para a DMU [...].
\end{abstract}

Quanto ao modelo chamado de DEA-BCC, proposto pelos pesquisadores Banker, Charnes e Cooper, em 1984, utiliza-se uma fronteira chamada VRS (Variable Returns to Scale) ou Retornos Variáveis à Escala. Esse modelo considera a possibilidade de rendimentos crescentes, decrescentes ou mesmo constantes de escala na fronteira eficiente. Vale ressaltar, conforme Casado e Souza (2007), que esse modelo os escores de eficiência dependem da orientação escolhida (input ou output). O modelo DEA-BCC, já consegue incorporar situações nas quais as DMUs estão sujeitas a variações na escala de produção. Sendo acrescentado neste modelo uma restrição adicional ao problema envelopado. Sua versão expressa matematicamente, na ótica de insumos, foi demostrada por Boueri (2015, p. 285):

\title{
$\operatorname{Min}: \theta_{i}$
}

$\{\theta, \lambda\}$

Sujeito a: 


$$
\begin{gathered}
\theta_{\mathrm{i}} x_{i}-X \lambda \geq \mathbf{0}_{m} \\
Q \lambda-\boldsymbol{q}_{\mathrm{i}} \geq \mathbf{0}_{s} \\
\boldsymbol{e}_{n} \lambda=1 \\
\lambda \geq \mathbf{0}_{n}
\end{gathered}
$$

Onde $\boldsymbol{e}_{n}$ é um vetor de dimensão n, exclusivamente composto por valores unitários. Observando a descrição do problema na equação acima, pode-se observar que há uma restrição a mais, a qual requer que a soma dos $\lambda^{\prime} s$ resulte em 1 (um), uma vez que:

$$
e_{n} \lambda=\lambda_{1}+\lambda_{2}+\cdots+\lambda_{n}=1
$$

O autor ressalta que essa restrição impede que uma DMU seja comparada com outras muito diferentes dela. Isso porque, ao forçar que os pesos das combinações lineares somem 1 (um), ela impossibilita que DMUs com vetores de insumo ou de produtos muito maiores ou muito menores possam estar no conjunto de referência da DMU investigada.

Importante destacar, Boueri (2015, p. 287): "De fato, quando o escore de eficiência é calculado pelo modelo com retornos variáveis de escala (BCC), os resultados são bem diferentes". Acrescenta, ainda, que outro ponto interessante que emerge na comparação dos modelos CCR e BCC é a possibilidade da decomposição de eficiência relativa da DMU em eficiência técnica e eficiência de escala. Essa decomposição é realizada dividindo-se $\theta_{c c k}$ por $\theta_{B C C}$.

Ou seja:

$$
\theta_{\text {escala }}=\frac{\theta_{\text {CCR }}}{\theta_{\text {Bcc }}}
$$

Os escores de eficiência calculados com retornos variáveis de escala nunca serão inferiores àqueles calculados com retornos constantes de escala, ou seja, sempre ocorrerá:

$$
\theta_{B C C} \geq \theta_{C C R}
$$

Tal fato ocorre, segundo o autor, porque no DEA-BCC as DMUs têm maior flexibilidade na avaliação de suas produções, logo:

$$
0 \leq \theta_{\text {escala }} \leq 1
$$

Esse escore será tanto maior quanto mais apropriada for a escala de operação da DMU. Assim, Boueri (2015, p. 287) conclui que "quando o cociente entre os dois escores é obtido, é 
possível avaliar quanto da ineficiência da DMU é devida a sua incapacidade técnica e quanto é devida ao fato de ela não estar produzindo na escala apropriada".

Ora, com advento do DEA-BCC houve a possibilidade de tratamento das economias de escala, conforme Negri (2003), já que neste modelo permitiu-se estimar uma fronteira de produção determinística com rendimentos variáveis a escala, ou seja, com retornos variáveis à escala. Diferente do modelo DEA-CCR cuja análise é de retornos constantes de escala.

Assim sendo, o DEA-BCC admite que a eficiência máxima varie em função da economia de escala e permite comparar unidades de portes distintos (BELLONI, 2000).

Sabe-se que esses dois modelos servem para maximizar a eficiência, seja orientado para o insumo (reduzindo o consumo de insumos, mantendo nível de produção), seja orientado para o produto (visando aumentar a produção, dados os níveis de insumos). Segundo Penã (2008, p. 94):

\begin{abstract}
No Modelo CCR com CRS, a fronteira eficiente é dada por uma reta a partir da origem até a unidade produtiva que forma o maior raio com o eixo do insumo. O Modelo BCC com retornos variáveis de escala (VRS) forma uma fronteira convexa eficiente com as melhores unidades, independentemente da escala de operação e, assim, passa a "envelopar" as unidades ineficientes para cada escala de produção. Ao trabalhar com uma fronteira convexa, considera as unidades com baixos níveis de consumo de insumos como unidades operadas com retornos crescentes de escala e vice-versa.
\end{abstract}

Após essa breve contextualização sobre Eficiência de Escala poderemos diferenciá-la em relação a Eficiência Técnica, uma vez que verificamos no estudo que nem todos os cursos considerados como eficientes técnicos estão na "Escala ótima". Ora, a distância da DMU à fronteira varia para cada unidade produtiva e essa distância estabelece a medida de eficiência técnica da DMU. Agora, quando a estimativa é baseada na produção, a eficiência é igual a produtividade total dos fatores. A eficiência de escala mensura essa produtividade total dos fatores da DMU em relação à escala mais produtiva, ou seja, a relação ao ponto em que a elasticidade é igual à unidade, segundo Negri e Freitas (2004).

Segundo Ferreira e Braga (2005), para analisar a eficiência de escala, torna-se necessário estimar a eficiência das DMUs utilizando os modelos CCR como BCC. No modelo CCR (produto) é possível obter a ET sobre o pressuposto de CRS (Retornos Constantes de Escala), também denominada de produtividade global ou eficiência produtiva. No modelo BCC (produto), extrai-se a medida de ET sobre os VRS (Retornos Variáveis de Escala). A Eficiência de Escala é calculada pela relação entre EF sobre o pressuposto CRS e ET sobre o pressuposto de VRS, conforme equação a seguir:

$$
\text { Es }=\frac{E t_{\text {CRS }}\left(X_{k}, Y_{k}\right)}{E t_{V R S}\left(X_{k}, Y_{k}\right)}
$$


Onde:

$E t_{C R S}\left(X_{k}, Y_{k}\right)$ é a ET ou produtiva (DEA-CCR);

$E t_{\text {VRS }}\left(X_{k}, Y_{k}\right)$ é a ET (DEA-BCC); e

Es $\left(X_{k}, Y_{k}\right)$ é a Eficiência de Escala.

Para Wanke e Affonso (2011, p. 56):

[...]além de proporcionar medidas de eficiência a DEA também oferece outras informações relevantes para as DMUs ineficientes. A DEA identifica a faceta eficiente sendo usada para comparação, a combinação de inputs que estão sendo usados de forma ineficiente, e o desvio de outputs específicos a partir do nível eficiente. A ineficiência de escala se deve ao aumento ou à redução dos retornos de escala, o que pode ser determinado inspecionando a soma dos pesos de acordo com as especificações do modelo CCR. Ora, se essa soma é igual a 1, a lei de retornos constantes de escala prevalece, mas se a soma for inferior ou superior a 1, respectivamente, retornos crescentes de escala e retornos decrescentes de escala prevalecem considerando um modelo orientado a inputs.

Por fim, para melhor ilustrar a Fronteira Eficiente em DEA, obtida com retornos constantes de escala (CCR) e com retornos variáveis de escala (BCC), utilizaremos a figura elaborada por Casado e Sousa (2007), que envolveu 01 (um) insumo e 01 (um) produto e comparou a eficiência técnica e de escala:

\section{Figura 1 - Eficiência Técnica e de Escala}

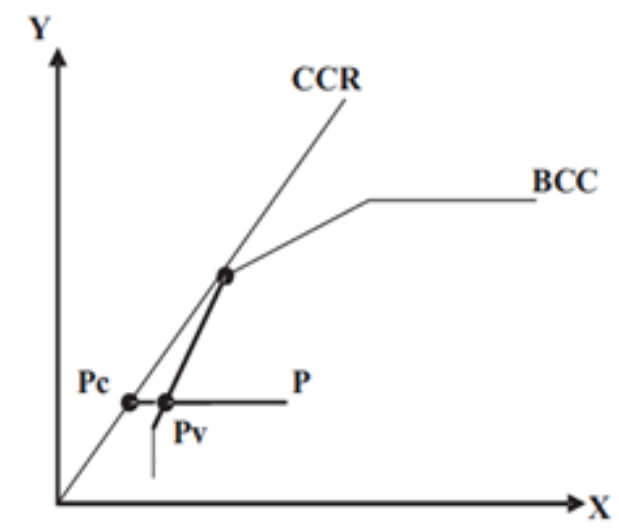

Fonte: Casado e Sousa (2007), com adaptações.

Y: Produto; X: Insumo; CCR: Retornos Constantes; BCC: Retornos Variáveis.

$\mathrm{O}$ ponto $\mathrm{P}$, na pressuposição de retornos constantes, a sua ineficiência técnica é dada pela distância PPc. A ineficiência técnica, na pressuposição de retornos variáveis, é dada pela distância PPv. E a diferença entre essas duas (PcPv) é a ineficiência de escala.

Com base na Figura 1, entendemos que o DEA, além de identificar as DMUs eficientes, permite medir e localizar a ineficiência e estimar uma função de produção linear por partes que fornece o benchmark para as DMUs ineficientes. Os autores, ressaltam, ainda, que se a 
medida de eficiência de escala for igual a 1 (um), a firma estará operando com retornos constantes à escala. No entanto, se for menor que 1 (um) poderão ocorrer retornos crescentes ou decrescentes.

Por fim, sobre o conceito de eficiência produtiva citamos Casado e Souza (2007) que a divide em dois componentes: a eficiência técnica e de escala. Para os autores, a eficiência técnica está associada a habilidade gerencial da organização e a eficiência de escala está associada as variações da produtividade decorrentes de mudanças na escala de produção. A importância da decomposição da eficiência resulta da capacidade de mensurar, para as universidades ineficientes, as magnitudes desses dois componentes da eficiência produtiva e, portanto, suas importâncias relativas, possibilitando estimar o impacto de ações corretivas na redução das ineficiências.

Já Mattos e Terra (2015, p. 214) conceituam eficiência técnica, pela ótica do produto, sendo:

[...] a diferença entre o montante efetivamente produzido com certa quantidade de insumos e o montante factível de ser produzido com certa quantidade de insumos e o montante factível de ser produzido, dada a tecnologia disponível. Esse montante factível de produção sob a ótica do produto é descrito pela Fronteira de Possibilidades de Produção.

No que tange a eficiência de escala os autores associam ao conceito a eficiência técnica. Ora, segundo eles, a ineficiência de escala surge quando a firma opera em uma escala desfavorável, ou seja, quando a produtividade média dos insumos não é máxima. Complementando o raciocínio o autor afirma:

a eficiência técnica associada à tecnologia com retornos constantes é denominada
eficiência técnica global e pode ser decomposta em um componente de eficiência
associada técnica pura local ou eficiência sob retornos variáveis a escala, e outro
componente que mede a distância entre a escala atual e a ideal (com retornos
constantes). Tal distância pode ser medida a partir da razão entre a produtividade
máxima (obtida na escala ótima) e a produtividade efetivamente obtida pela firma se
ela fosse tecnicamente eficiente em sua escala atual de operação.

A Figura 2, a seguir, elaborada por Penã (2008), tem como intuito demonstrar de forma ainda mais clara a conceituação de eficiência. A partir desse entendimento pode-se melhor identificar os cursos ou DMUs que estão sobre a fronteira de eficiência técnica e as que atingiram a fronteira de escala. Ora, cabe destacar que o conjunto de alternativas de produção é formado por toda área abaixo da curva de máxima produção (Fronteira de Possibilidade de Produção - FPP). 
Figura 2 - Função Produção

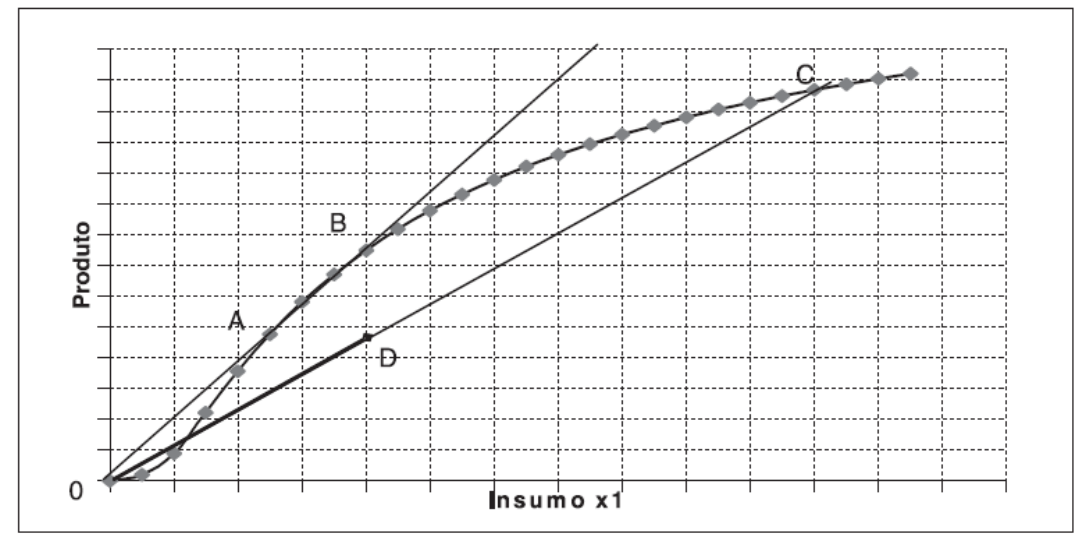

Fonte: PENÃ (2008)

Quanto a Figura 2, temos que: o segmento 0A demonstra os retornos crescentes de escala; no segmento de A a B são demonstrados os retornos constantes; e o seguimento a partir de B os retornos decrescentes. Observando a figura percebemos que os pontos A, B e C são eficientes. Todavia, ao passar do ponto A para o $\mathrm{C}$ tem-se queda de produtividade média parcial, que é medida pela inclinação da reta que une o zero (origem) a qualquer ponto. Os pontos $\mathrm{D}$ e $\mathrm{C}$ apresentam a mesma produtividade quando o ponto $\mathrm{D}$, diferentemente do ponto C, é ineficiente, uma vez que com o seu nível de insumo a produção poderia alcançar o mesmo do ponto B.

Cabe destacar, que há vários estudos que utilizam o DEA para mensurar a eficiência de DMUs, construindo a fronteira de produção com os pontos que atingiram o máximo de produto ou produtividade, dado determinado nível de insumos ou com o mínimo de inputs para dado nível de outputs. Por exemplo, nos Estados Unidos, a utilização do DEA, foi efetuada para comparar os resultados de instituições de ensino de nível superior públicas e privadas, Rhodes e Southwick (1986) apud Wong e Beasley (1990). No Reino Unido essa técnica foi utilizada para avaliar 90 (noventa) instituições de ensino superior, ponderando-se: governo/sociedade; instituições (departamento, servidores) e os estudantes Sarrico (1997) apud Costa, Ramos e Souza (2010). Na Noruega a técnica do DEA foi utilizada para apontar os resultados das instituições de ensino mais eficientes com relação aos serviços prestados e apontando efeitos positivos quanto a produtividade, conforme Forsund e Kalhagen (1999) apud Costa, Ramos e Souza (2010). No estudo feito nas universidades britânicas detectou-se um aumento significativo na eficiência técnica no período de 1987-1988 e 1990-1991, segundo Flegg et al. (2004) apud Costa, Ramos e Souza (2010). Além de estudos nas universidades públicas portuguesas, australianas, europeias e também brasileiras. 


\section{RESULTADOS}

Para apuração dos dados coletados, foi utilizado o software STATA 1.0 e o método de Análise Envoltória de Dados (DEA) para elaboração da fronteira de eficiência técnica.

\subsection{Eficiência Técnica}

$\mathrm{Na}$ análise efetuada, observa-se que há 8 (oito) cursos eficientes tecnicamente, uma vez que apresentaram escores iguais a 1, ou seja, estão sobre a fronteira de eficiência técnica: Relações internacionais; Serviço Social; Enfermagem; Agronomia; Farmácia; Medicina; Odontologia e Design.

No entanto, a grande maioria dos cursos avaliados, ou seja, 21 (vinte e um) apresentaram ineficiência técnica (escore abaixo de 1): Arquivologia; Direito; Engenharia Civil; Nutrição; Matemática; Ciências Contábeis; Estatística; Física; Publicidade e Propaganda; Bacharelado em Ciências da Computação; Jornalismo; Administração; Química; Música; Teatro; Biologia; Geografia; História e por último Filosofia.

Vale destacar que, nos anos de 2008, 2009 e 2010, da média de cursos de graduação ofertados pela UnB, ou seja, cerca de 115 cursos, foram avaliados na amostra do Enade uma média de 13 cursos, o que representa $11,3 \%$ do total da média dos cursos de graduação ofertados nos referidos anos na UnB. A amostra utilizada neste estudo, totalizando 27 (vinte e sete) cursos, representam um percentual de 23,5\% da média total de cursos ofertados pela UnB nos referidos anos. Diante disso, 70,4\% dos cursos apresentaram escores de ineficiência técnica, ou seja, um percentual considerável.

Pode-se visualizar na Tabela 8 abaixo, que os cursos de Relações Internacionais e Serviço Social estão exatamente na mesma posição na fronteira de eficiência técnica, ambos com escore 1 no ranking. Tal fato ocorre devido as "folgas" existentes entre eles, ou seja, os chamados "slacks". Isso significa que esses 8 (oito) cursos, acima listados, mesmo sendo eficientes tecnicamente podem seguir uma classificação dada pela utilização de menos insumos. A fim de colaborar com esse entendimento e facilitar a compreensão do ranking dos cursos eficientes tecnicamente, demostraremos graficamente o sentido do termo "slack" por meio da Figura 3 adaptada de Varian (1992). 
Tabela 8 - Ranking relativo a Eficiência Técnica (ET)

\begin{tabular}{|c|c|c|c|}
\hline DMU & Cursos avaliados & Ranking ET & escore \\
\hline 25 & Relações Internacionais & 1 & 1000000 \\
\hline 26 & Serviço Social & 1 & 1000000 \\
\hline 9 & Enfermagem & 3 & 1000000 \\
\hline 2 & Agronomia & 4 & 1000000 \\
\hline 12 & Farmácia & 5 & 1000000 \\
\hline 19 & Medicina & 6 & 1000000 \\
\hline 22 & Odontologia & 7 & 1000000 \\
\hline 7 & Design & 8 & 1000000 \\
\hline 3 & Arquivologia & 9 & 0.957150 \\
\hline 8 & Direito & 10 & 0.935336 \\
\hline 10 & Engenharia Civil & 11 & 0.903160 \\
\hline 21 & Nutrição & 12 & 0.897980 \\
\hline 18 & Matemática & 13 & 0.855200 \\
\hline 6 & Ciências contábeis & 14 & 0.829470 \\
\hline 11 & Estatística & 15 & 0.828749 \\
\hline 14 & Física & 16 & 0.822794 \\
\hline 23 & Publicidade e Propaganda & 17 & 0.816055 \\
\hline 4 & Bacharelado Ciência da Computação & 18 & 0.806502 \\
\hline 17 & Jornalismo & 19 & 0.785081 \\
\hline 1 & Administração & 20 & 0.779330 \\
\hline 24 & Química & 21 & 0.772586 \\
\hline 20 & Música & 22 & 0.760185 \\
\hline 27 & Teatro & 23 & 0.759560 \\
\hline 5 & Biologia & 24 & 0.741856 \\
\hline 15 & Geografia & 25 & 0.715597 \\
\hline 16 & História & 26 & 0.710779 \\
\hline 13 & Filosofia & 27 & 0.600646 \\
\hline
\end{tabular}

Na Figura 3, pode-se observar que os pontos B e C são tecnicamente eficientes, pois estão sobre a fronteira. Já o ponto A demonstra que o produtor é ineficiente, pois se encontra sob a fronteira de eficiência técnica. Importante destacar que entre os pontos B e C (ambos eficientes) o ponto $\mathrm{C}$, caso houvesse um ranking, seria o mais eficiente, uma vez que comparado ao ponto B está sobre a fronteira utilizando menos insumos. Debreu (1951) e Farrel (1957) afirmam que uma unidade produtiva com escore 1 ou $100 \%$ indica que seu desempenho não pode ser melhorado por outra. Se a eficiência for menor ou maior que 1 , dependendo da ótica utilizada (input ou output), respectivamente, esse número indicará o nível de ineficiência. 
Figura 3 - Eficiência Técnica

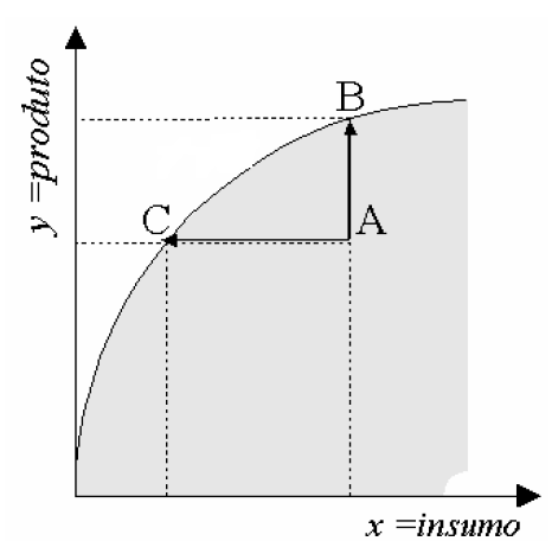

Fonte: Varian (1992), com adaptações.

Observa-se, a partir dos dados da Tabela 9, que apenas 29,63\% dos cursos avaliados neste estudo apresentaram eficiência técnica, ou seja, um pouco mais que $25 \%$ do total dos cursos selecionados na amostra deste estudo. Ressalta-se, que o maior percentual, ou seja, cerca de 70,37\% são dos cursos avaliados como ineficientes tecnicamente. Sabemos que os cursos que estão localizados sobre a fronteira de eficiência, principalmente o curso de Relações Internacionais, podem ser considerados como referência para aqueles cursos que estão abaixo da fronteira.

$\mathrm{Na}$ Tabela 9 a seguir, separamos os cursos em grupos por níveis: eficiência e ineficiência. A ineficiência está separada por: fraca, moderada e forte, dependo do escore de cada curso. Além disso, demonstramos o percentual de DMUs que estão localizadas em cada nível, bem como a quantidade de DMUs pertencentes a cada um dos quatro níveis identificados com suas respectivas DMUs e a posição delas no ranking da fronteira de eficiência técnica:

Tabela 9 - Percentual de cursos por níveis de eficiência e ineficiência

\begin{tabular}{lcccc}
\hline \multicolumn{1}{c}{ Níveis } & \% & Qtd. DMUs & Identificação das DMUs & Posição no Rank ET \\
\hline $\begin{array}{l}\text { Eficiência Técnica } \\
\text { Escore =1) }\end{array}$ & 29,63 & 8 & $25 ; 26 ; 9 ; 2 ; 12 ; 19 ; 22$ e 7 & $1^{\circ}$ ao $8^{\circ}$ lugar \\
$\begin{array}{l}\text { Ineficiência Fraca } \\
\text { Escore de 0,8 a 0,99) }\end{array}$ & 37,04 & 10 & $3 ; 8 ; 10 ; 21 ; 18 ; 6 ; 11 ; 14 ; 23$ e 4 & $9^{\circ}$ ao 18 \\
$\begin{array}{l}\text { Ineficiência Moderada } \\
\text { (Escore de 0,6 a 0,79) }\end{array}$ & 33,33 & 9 & $17 ; 1 ; 24 ; 20 ; 27 ; 5 ; 15 ; 16$ e 13 & 19 ao 27 \\
$\begin{array}{l}\text { Ineficiência Forte } \\
\text { Escore < 0,59) }\end{array}$ & - & - & & - \\
\hline \begin{tabular}{l} 
Total \\
\hline
\end{tabular} & 100 & 27 & - & - \\
\hline
\end{tabular}

Fonte: Elaboração própria

Nota: sinal convencional utilizado

- Não há dado 
Observa-se, com base nas variáveis utilizadas nesse estudo, que quase 30\% das DMUs estão sobre a fronteira de eficiência técnica. No entanto, 70,4\% apresentam-se abaixo da fronteira de eficiência técnica. Nota-se que 37,04\% dos cursos apresentam ineficiência fraca, ou seja, estão próximos à fronteira de eficiência técnica. Isso significa que o desempenho dessas DMUs, localizadas nesse nível de ineficiência, poderão ser melhorados se elas utilizarem as DMUs eficientes como referência. Percebe-se que é grande o percentual dos cursos com eficiência moderada, ou seja, 33,33\%, essas DMUs também poderão se tornar eficientes tecnicamente, mas seus escores estão entre 0,6 a 0,79 . O ponto positivo é que não há cursos com ineficiência forte, ou seja, com escores abaixo de 0,59 , e a tendência é que busquem atingir a eficiência uma vez que seus escores estão próximos a 1.

Na Tabela 10 a seguir, os 27 (vinte e sete) cursos avaliados neste estudo foram separados em 3 (três) grupos. Cada grupo contém 09 (nove) cursos: no grupo I estão os cursos com melhores escores; no grupo II estão os cursos com escores medianos; e no grupo III têmse os cursos com menores escores.

Tabela 10 - Classificação dos cursos por Grupo de acordo com escores

\begin{tabular}{clcclcccc}
\hline & \multicolumn{1}{c}{$\begin{array}{c}\text { GRUPO I } \\
\text { (escores melhores) }\end{array}$} & \multicolumn{4}{c}{$\begin{array}{c}\text { GRUPO II } \\
\text { (escores medianos) }\end{array}$} & \multicolumn{3}{c}{$\begin{array}{c}\text { GRUPO III } \\
\text { (escores menores) }\end{array}$} \\
\hline DMU & Cursos & escores & DMU & Cursos & escores & DMU & Cursos & escores \\
\hline $\mathbf{2 5}$ & Rel. Internacionais & $\mathbf{1}$ & 8 & Direito & $\mathbf{0 . 9 6}$ & 17 & Jornalismo & $\mathbf{0 . 7 8}$ \\
$\mathbf{2 6}$ & Serviço Social & $\mathbf{1}$ & 10 & Eng. Civil & $\mathbf{0 . 9 3}$ & 1 & Administração & $\mathbf{0 . 7 8}$ \\
$\mathbf{9}$ & Enfermagem & $\mathbf{1}$ & 21 & Nutrição & $\mathbf{0 . 9 0}$ & 24 & Química & $\mathbf{0 . 7 7}$ \\
$\mathbf{2}$ & Agronomia & $\mathbf{1}$ & 18 & Matemática & $\mathbf{0 . 9 0}$ & 20 & Música & $\mathbf{0 . 7 6}$ \\
$\mathbf{1 2}$ & Farmácia & $\mathbf{1}$ & 6 & C. Contábeis & $\mathbf{0 . 8 5}$ & 27 & Teatro & $\mathbf{0 . 7 6}$ \\
$\mathbf{1 9}$ & Medicina & $\mathbf{1}$ & 11 & Estatística & $\mathbf{0 . 8 3}$ & 5 & Biologia & $\mathbf{0 . 7 4}$ \\
$\mathbf{2 2}$ & Odontologia & $\mathbf{1}$ & 14 & Física & $\mathbf{0 . 8 2}$ & 15 & Geografia & $\mathbf{0 . 7 1}$ \\
$\mathbf{7}$ & Design & $\mathbf{1}$ & 23 & Publ. e Prop. & $\mathbf{0 . 8 2}$ & 16 & História & $\mathbf{0 . 7 1}$ \\
$\mathbf{3}$ & Arquivologia & $\mathbf{0 , 9 6}$ & 4 & B. C. Comput. & $\mathbf{0 . 8 1}$ & 13 & Filosofia & $\mathbf{0 . 6 0}$ \\
\hline Fonte: Elaboração própria. & & \multicolumn{1}{c}{} & & &
\end{tabular}

Segue a análise de cada um dos 3 Grupos:

Grupo I: estão os 9 (nove) cursos que apresentaram os maiores escores. Dentre eles 08 (oito) apresentaram eficiência técnica, quais sejam: Relações Internacionais; Serviço Social; Enfermagem; Agronomia; Farmácia; Medicina; Odontologia e Design atingiram escore 1 ou 100\%. Somente 01 (um) curso desse grupo não apresentou eficiência técnica: Arquivologia, com escore 0,96. Ressalta-se que o referido curso está abaixo da fronteira técnica, no entanto, está bem próximo de alcançar a eficiência. Dos cursos que atingiram a eficiência técnica destacamos o de Relações Internacionais; Design e Medicina, pois esses apresentaram as 
melhores notas média de formação dos ingressantes e concluintes no Enade. Além disso, o curso de Medicina foi o que apresentou a segunda maior média salarial para pagamento do corpo docente, ficando atrás somente do curso de Relações Internacionais. Em relação ao indicador da RAP o curso de Medicina apresentou 12,7\% o que é razoavelmente alto, estando abaixo somente dos cursos de Agronomia (16,4\%), Odontologia (13,7\%) e Farmácia (12,9\%).

O curso de Farmácia, apesar de apresentar um bom indicador da RAP, é o curso com a terceira maior média salarial dos docentes. O curso de Odontologia apresenta-se na $7^{\mathrm{a}}$ posição em relação a todos os cursos com relação à média salarial dos docentes DE. Quanto as notas do Enade seus alunos ingressantes e concluintes obtiveram a $9^{\text {a }}$ maior nota.

O curso de Agronomia, localizado na $4^{\mathrm{a}}$ posição no ranking de Eficiência Técnica (ET), é o curso com melhor índice da RAP. No entanto, é o $4^{\circ}$ curso com maiores gastos com pagamento de docentes (média salarial de docentes DE). Quanto às notas médias de formação de alunos ingressantes e concluintes, o referido curso ocupa a $21^{\mathrm{a}}$ e $16^{\mathrm{a}}$ posições, respectivamente.

O curso de Enfermagem, que ficou na $3^{\text {a }}$ posição do ranking de ET, não apresentou um bom indicador da RAP, pois está na $19^{a}$ posição. Com relação ao gasto com pagamento de docentes o seu custo é alto e o curso está na $8^{\mathrm{a}}$ posição. Na variável relativa à nota média de formação dos alunos concluintes ficou na penúltima posição, ou seja, na $26^{a}$ posição, apresentado uma nota muito baixa 9,9. Os alunos (ingressantes) tiveram a $13^{\text {a }}$ melhor nota no Enade $(51,4)$. Os alunos do curso de Design foram muito bem nas notas do Enade, ficando com a segunda melhor nota, tanto os ingressantes quanto os concluintes. No que tange aos gastos com pagamento de docentes, esse curso ficou na $17^{a}$ posição e o indicador da RAP o curso está na $13^{\mathrm{a}}$ posição.

O curso de Serviço Social, $2^{\mathrm{a}}$ posição no ranking da ET, obteve a menor nota de formação dos alunos ingressantes e concluintes do Enade, quais sejam: 5,9 e 7,2, respectivamente. Contudo, ocupou a $6^{\text {a }}$ posição, em comparação com os outros cursos, no que tange a RAP. No total de gastos com pagamento de docentes ficou em $14^{\mathrm{a}}$ posição dos 27 cursos. O curso de Arquivologia ficou na $6^{a}$ posição dos maiores salários pagos aos docentes, e na $7^{\mathrm{a}}$ posição em relação as notas dos alunos ingressantes. Quanto a nota dos concluintes o curso baixou para $20^{a}$ posição. Na Relação Aluno Professor está na $9^{a}$ posição. Ressalta-se que o curso de Arquivologia apesar de ser considerado ineficiente tecnicamente, aparece em $9^{a}$ posição no ranking com indicador 0,96 , possuindo ineficiência fraca, pois está bem próximo, ou seja, numa distância de 0,4 da fronteira de eficiência. A Tabela 11, a seguir, 
sintetiza os resultados descritos acima trazendo os cursos, seu ranking de eficiência técnica, os percentuais da RAP, valores relativos a média salarial mensal dos docentes DE e as notas de formação média dos alunos ingressantes e concluintes do Enade, seguidos em cada coluna pela sua respectiva classificação em cada um dos itens.

Tabela 11 - Cursos do Grupo I e suas variáveis (inputs e output)

\begin{tabular}{clcccc}
\hline \multirow{2}{*}{$\begin{array}{c}\text { Rank } \\
(\mathbf{E T})\end{array}$} & Cursos & \% RAP & Gasto $(\mathbf{R} \$)$ & $\begin{array}{c}\text { Nota Enade } \\
(\text { Ingressantes) }\end{array}$ & $\begin{array}{c}\text { Output } \\
\text { Nota Enade } \\
\text { (Concluintes) }\end{array}$ \\
\hline $\mathbf{1}$ & Rel. Internacionais & $3,29 \%\left(22^{\mathrm{a}}\right)$ & $13.721,70\left(1^{\mathrm{a}}\right)$ & $75,9\left(1^{\mathrm{a}}\right)$ & $74,1\left(1^{\mathrm{a}}\right)$ \\
$\mathbf{1}$ & Serviço Social & $8,22 \%\left(6^{\mathrm{a}}\right)$ & $9.010,71\left(14^{\mathrm{a}}\right)$ & $5,9\left(27^{\mathrm{a}}\right)$ & $7,2\left(27^{\mathrm{a}}\right)$ \\
$\mathbf{3}$ & Enfermagem & $4,02 \%\left(19^{\mathrm{a}}\right)$ & $10.229,00\left(8^{\mathrm{a}}\right)$ & $51,4\left(13^{\mathrm{a}}\right)$ & $9,9\left(26^{\mathrm{a}}\right)$ \\
$\mathbf{4}$ & Agronomia & $16,36 \%\left(1^{\mathrm{a}}\right)$ & $11.501,40\left(4^{\mathrm{a}}\right)$ & $46,7\left(21^{\mathrm{a}}\right)$ & $50,8\left(16^{\mathrm{a}}\right)$ \\
$\mathbf{5}$ & Farmácia & $12,86 \%\left(3^{\mathrm{a}}\right)$ & $11.530,90\left(3^{\mathrm{a}}\right)$ & $53,7\left(10^{\mathrm{a}}\right)$ & $53\left(15^{\mathrm{a}}\right)$ \\
$\mathbf{6}$ & Medicina & $12,67 \%\left(4^{\mathrm{a}}\right)$ & $11.550,60\left(2^{\mathrm{a}}\right)$ & $58,6\left(5^{\mathrm{a}}\right)$ & $65\left(4^{\mathrm{a}}\right)$ \\
$\mathbf{7}$ & Odontologia & $13,7 \%\left(2^{\mathrm{a}}\right)$ & $10.730,40\left(7^{\mathrm{a}}\right)$ & $54,2\left(9^{\mathrm{a}}\right)$ & $56\left(9^{\mathrm{a}}\right)$ \\
$\mathbf{8}$ & Design & $6,7 \%\left(13^{\mathrm{a}}\right)$ & $8.394,60\left(17^{\mathrm{a}}\right)$ & $72,3\left(2^{\mathrm{a}}\right)$ & $72,1\left(2^{\mathrm{a}}\right)$ \\
$\mathbf{9}$ & Arquivologia & $7,46 \%\left(9^{\mathrm{a}}\right)$ & $10.942,00\left(6^{\mathrm{a}}\right)$ & $56,5\left(7^{\mathrm{a}}\right)$ & $45,9\left(20^{\mathrm{a}}\right)$ \\
\hline
\end{tabular}

Fonte: Elaboração própria

Nota-se que o curso de Relações Internacionais, que está no topo do ranking de ET, apresentou as três maiores variáveis (gasto e as duas notas Enade), já seu indicador (RAP) apresenta baixo percentual e isso o colocou na $22^{\mathrm{a}}$ posição, relativa a esta variável específica.

O curso de Serviço Social apresentou as duas menores notas do Enade. Quanto ao gasto com salário dos docentes está na $14^{\mathrm{a}}$ posição em relação aos 27 cursos analisados. No que tange a RAP o curso está na $6^{\mathrm{a}}$ posição em relação aos demais cursos. A Agronomia apresenta o melhor indicador da RAP e está na $4^{\text {a }}$ posição em relação ao gasto com a média salarial dos docentes. Já em relação ao desempenho dos alunos nas notas do Enade o curso está na $21^{\text {a }}$ posição (ingressantes) e na $16^{\text {a }}$ (concluintes) em relação aos demais cursos.

Grupo II: os 09 (nove) cursos classificados neste grupo possuem escores abaixo de 1, ou seja, são ineficientes tecnicamente, quais sejam: Direito; Engenharia Civil; Nutrição; Matemática; Ciências Contábeis; Estatística; Física; Publicidade e Propaganda e Bacharelado em Ciência da Computação. Contudo, considerando que os escores variam de 0,81 a 0,96 verifica-se uma ineficiência relativamente fraca, ou seja, apesar desses cursos estarem localizados abaixo da fronteira de eficiência técnica, apresentam escores próximos a 1. Desses cursos, destacamos o de Estatística que apresentou o melhor indicador RAP, localizado na $5^{\text {a }}$ posição. No entanto, foi o curso classificado na $9^{a}$ posição em relação aos gastos com pagamento de docentes. Quanto a nota dos alunos concluintes o curso ocupou a $10^{\mathrm{a}}$ posição, 
enquanto na nota dos alunos ingressantes ficou na $19^{\mathrm{a}}$ posição. Ora, apesar de ser ineficiente este curso está posicionado na $15^{\mathrm{a}}$ do ranking de $E T$, ou seja, pode-se considerar como uma ineficiência fraca.

Os cursos de Direito; Engenharia Civil; Nutrição; Matemática; Ciências Contábeis; Física; Publicidade e Propaganda e Bacharelado em Ciências da Computação foram todos classificados com ineficiência fraca. Os alunos (concluintes) dos cursos de Bacharelado em Ciências da Computação; Nutrição e Física foram os que apresentaram as notas medianas do Enade. Destacamos o curso de Bacharelado de Ciências da Computação que apresentou o menor gasto médio dos docentes ( $27^{\mathrm{a}}$ posição), enquanto a sua RAP o curso está na $11^{\mathrm{a}}$ posição. Os alunos ingressantes e concluintes do curso de Direito apresentaram a terceira melhor nota. Apesar disso sua RAP não é muito boa, está localizado na $21^{a}$ posição.

As notas de formação geral dos alunos de Publicidade e Propaganda para ingressantes e concluintes estão entre as menores, ambas no $24^{\circ}$ lugar (notas dos ingressantes e concluintes), perdendo somente para os cursos de Filosofia, Teatro e Serviço Social (ingressantes) e Geografia, Enfermagem e novamente Serviço Social (concluintes).

O curso de Ciências Contábeis, apesar de ser ineficiente, ocupa a $14^{\mathrm{a}}$ posição no ranking da ET, ou seja, possui ineficiência fraca. O seu indicador RAP é baixo, pois está na penúltima posição desse ranking (ocupando $26^{\mathrm{a}}$ posição). Apesar disso, é o curso com menor gasto em relação a média salarial dos docentes localizado na $27^{a}$ posição do ranking dessa variável. Já seus alunos tanto ingressantes quanto os concluintes apresentaram ótimas notas no Enade, pois o curso está na $4^{\mathrm{a}}$ e $6^{\mathrm{a}}$ posições, respectivamente. A Tabela 12 sintetiza as informações acima descritas:

Tabela 12 - Cursos do Grupo II e suas variáveis (inputs e output)

\begin{tabular}{clcccc}
\hline \multirow{2}{*}{$\begin{array}{r}\text { Rank } \\
(\mathbf{E T})\end{array}$} & Cursos & \% RAP & Gasto $(\mathbf{R} \$)$ & $\begin{array}{c}\text { Nota Enade } \\
\text { (Ingressantes) }\end{array}$ & $\begin{array}{c}\text { Notp Ent } \\
\text { (Concluintes) }\end{array}$ \\
\cline { 2 - 5 } $\mathbf{1 0}$ & Direito & $3,44 \%\left(21^{\mathrm{a}}\right)$ & $9.248,17\left(12^{\mathrm{a}}\right)$ & $67,8\left(3^{\mathrm{a}}\right)$ & $65,8\left(3^{\mathrm{a}}\right)$ \\
$\mathbf{1 1}$ & Eng. Civil & $7,46 \%\left(8^{\mathrm{a}}\right)$ & $7.295,47\left(20^{\mathrm{a}}\right)$ & $57,5\left(6^{\mathrm{a}}\right)$ & $57,2\left(8^{\mathrm{a}}\right)$ \\
$\mathbf{1 2}$ & Nutrição & $7,63 \%\left(7^{\mathrm{a}}\right)$ & $10.992,70\left(5^{\mathrm{a}}\right)$ & $50,4\left(15^{\mathrm{a}}\right)$ & $53,7\left(12^{\mathrm{a}}\right)$ \\
$\mathbf{1 3}$ & Matemática & $6,35 \%\left(14^{\mathrm{a}}\right)$ & $5.996,78\left(26^{\mathrm{a}}\right)$ & $52,0\left(12^{\mathrm{a}}\right)$ & $46,8\left(19^{\mathrm{a}}\right)$ \\
$\mathbf{1 4}$ & C. Contábeis & $2,12 \%\left(26^{\mathrm{a}}\right)$ & $7.430,54\left(19^{\mathrm{a}}\right)$ & $59,0\left(4^{\mathrm{a}}\right)$ & $61,6\left(6^{\mathrm{a}}\right)$ \\
$\mathbf{1 5}$ & Estatística & $9,06\left(5^{\mathrm{a}}\right)$ & $9.919,31\left(9^{\mathrm{a}}\right)$ & $47,4\left(19^{\mathrm{a}}\right)$ & $55,1\left(10^{\mathrm{a}}\right)$ \\
$\mathbf{1 6}$ & Física & $7,28 \%\left(10^{\mathrm{a}}\right)$ & $7.095,51\left(21^{\mathrm{a}}\right)$ & $48,6\left(18^{\mathrm{a}}\right)$ & $48,3\left(17^{\mathrm{a}}\right)$ \\
$\mathbf{1 7}$ & Publ. e Prop. & $6,02 \%\left(15^{\mathrm{a}}\right)$ & $9.507,69\left(10^{\mathrm{a}}\right)$ & $42,1\left(24^{\mathrm{a}}\right)$ & $41,1\left(24^{\mathrm{a}}\right)$ \\
$\mathbf{1 8}$ & B. C. Comput. & $6,96 \%\left(11^{\mathrm{a}}\right)$ & $5.884,09\left(27^{\mathrm{a}}\right)$ & $50,1\left(17^{\mathrm{a}}\right)$ & $54,9\left(11^{\mathrm{a}}\right)$ \\
\hline
\end{tabular}


Grupo III: neste último grupo estão os 09 (nove) cursos que apresentaram os escores mais baixos. O referido grupo é composto pelos seguintes cursos: Jornalismo; Administração; Química; Música; Teatro; Biologia; Geografia; História e Filosofia.

Apesar de ser o grupo com as piores posições seus escores foram considerados como ineficiência moderada.

Desses cursos, destacamos que os alunos (concluintes) dos cursos de Jornalismo, Música, Filosofia e Geografia que obtiveram as menores notas de formação do Enade. Já nos cursos de Química; História e Teatro os alunos concluintes obtiveram notas medianas do Enade. Os cursos de Teatro, Música, Filosofia e Química apresentaram índice mediano na relação professor por aluno. O curso de Teatro obteve a penúltima nota (26a posição) na classificação dos alunos ingressantes. Já os cursos de Jornalismo, Administração, Geografia e Biologia que apresentaram os piores índices dessa Relação de Aluno Professor.

Quanto aos gastos com salários de docentes os cursos de Geografia, Química, História; Filosofia; tiveram menores gastos, enquanto os cursos de Biologia; Música e Teatro tiveram gastos medianos. A Tabela 13 demonstra os números relativos aos cursos desse grupo III.

Tabela 13 - Cursos do Grupo III e suas variáveis (inputs e output)

\begin{tabular}{|c|c|c|c|c|c|}
\hline \multirow[b]{2}{*}{$\begin{array}{l}\operatorname{Rank} \\
(\mathbf{E T})\end{array}$} & \multirow[b]{2}{*}{ Cursos } & \multicolumn{3}{|c|}{ Inputs } & \multirow{2}{*}{$\begin{array}{c}\text { Output } \\
\text { Nota Enade } \\
\text { (Concluintes) }\end{array}$} \\
\hline & & $\% \mathbf{R A P}$ & Gasto (R\$) & $\begin{array}{c}\text { Nota Enade } \\
\text { (Ingressantes) }\end{array}$ & \\
\hline 19 & Jornalismo & $2,68 \%\left(24^{a}\right)$ & $8.952,14\left(15^{a}\right)$ & $50,3\left(16^{a}\right)$ & $43,1\left(22^{a}\right)$ \\
\hline 20 & Administração & $3,08 \%\left(23^{a}\right)$ & $9.448,05\left(11^{\mathrm{a}}\right)$ & $55,3\left(8^{a}\right)$ & $62,3\left(5^{\mathrm{a}}\right)$ \\
\hline 21 & Química & $4,34 \%\left(18^{a}\right)$ & $6.121,26\left(24^{a}\right)$ & $51,1\left(14^{\mathrm{a}}\right)$ & $53,1\left(13^{a}\right)$ \\
\hline 22 & Música & $5,71 \%\left(16^{\mathrm{a}}\right)$ & $8.813,41\left(16^{a}\right)$ & $44,8\left(22^{a}\right)$ & $44,9\left(21^{a}\right)$ \\
\hline 23 & Teatro & $6,73 \%\left(12^{a}\right)$ & $9.013,16\left(13^{\mathrm{a}}\right)$ & $40,6\left(25^{a}\right)$ & $47,2\left(18^{a}\right)$ \\
\hline 24 & Biologia & $0,65\left(27^{a}\right)$ & $8.249,22\left(18^{a}\right)$ & $52,4\left(11^{a}\right)$ & $60,3\left(7^{a}\right)$ \\
\hline 25 & Geografia & $2,56 \%\left(25^{\mathrm{a}}\right)$ & $6.106,91\left(25^{\mathrm{a}}\right)$ & $43,8\left(23^{a}\right)$ & $35,6\left(25^{a}\right)$ \\
\hline 26 & História & $3,50 \%\left(20^{a}\right)$ & $6.692,00\left(23^{a}\right)$ & $47,4\left(20^{a}\right)$ & $53,0\left(14^{a}\right)$ \\
\hline 27 & Filosofia & $4,61 \%\left(17^{a}\right)$ & $7.023,36\left(22^{\mathrm{a}}\right)$ & $32,2\left(26^{a}\right)$ & $42,3\left(23^{a}\right)$ \\
\hline
\end{tabular}

Fonte: Elaboração própria

Ora, na Tabela 14 consideramos somente os cursos ineficientes tecnicamente, ou seja, cerca de 70,37\% do total dos cursos analisados neste estudo. São 19 (dezenove) cursos, conforme listados abaixo, com seus respectivos escores e a distância da fronteira de eficiência técnica. Senão vejamos: 
Tabela 14 - Relação dos cursos com ineficiência técnica

\begin{tabular}{llcc}
\hline DMU & Cursos & escores & Distância da Fronteira (1- escore) \\
\hline $\mathbf{3}$ & Arquivologia & 0,95715 & 0,042850 \\
$\mathbf{8}$ & Direito & 0,935336 & 0,064664 \\
$\mathbf{1 0}$ & Engenharia Civil & 0,90316 & 0,096840 \\
$\mathbf{2 1}$ & Nutrição & 0,89798 & 0,102020 \\
$\mathbf{1 8}$ & Matemática & 0,85520 & 0,144800 \\
$\mathbf{6}$ & Ciências contábeis & 0,82947 & 0,170530 \\
$\mathbf{1 1}$ & Estatística & 0,828749 & 0,171251 \\
$\mathbf{1 4}$ & Física & 0,822794 & 0,177206 \\
$\mathbf{2 3}$ & Publicidade e Propaganda & 0,816055 & 0,183945 \\
$\mathbf{4}$ & Bacharelado Ciência da & 0,806502 & 0,193498 \\
& Computação & & \\
$\mathbf{1 7}$ & Jornalismo & 0,785081 & 0,214919 \\
$\mathbf{1}$ & Administração & 0,779330 & 0,220670 \\
$\mathbf{2 4}$ & Química & 0,772586 & 0,227414 \\
$\mathbf{2 0}$ & Música & 0,760185 & 0,239815 \\
$\mathbf{2 7}$ & Teatro & 0,759560 & 0,240440 \\
$\mathbf{5}$ & Biologia & 0,741856 & 0,258144 \\
$\mathbf{1 5}$ & Geografia & 0,715597 & 0,284403 \\
$\mathbf{1 6}$ & História & 0,710779 & 0,289221 \\
$\mathbf{1 3}$ & Filosofia & 0,600646 & 0,399354 \\
\hline
\end{tabular}

Fonte: Elaboração própria.

A Tabela 15, a seguir, foi elaborada para demonstrar que dos 27 (vinte e sete) cursos avaliados neste estudo, na média, poderiam alcançar o mesmo nível de output com a redução de recursos na ordem de $16,86 \%$ (1-0,831358). 
Tabela 15 - Redução média de inputs

\begin{tabular}{lc}
\hline Cursos & escores \\
\hline Relações Internacionais & 1,000000 \\
Serviço Social & 1,000000 \\
Enfermagem & 1,000000 \\
Agronomia & 1,000000 \\
Farmácia & 1,000000 \\
Medicina & 1,000000 \\
Odontologia & 1,000000 \\
Design & 1,000000 \\
Arquivologia & 0,957150 \\
Direito & 0,935336 \\
Engenharia Civil & 0,903160 \\
Nutrição & 0,897980 \\
Matemática & 0,855200 \\
Ciências contábeis & 0,829470 \\
Estatística & 0,828749 \\
Física & 0,822794 \\
Publicidade e Propaganda & 0,816055 \\
Bacharelado Ciência da Computação & 0,806502 \\
Jornalismo & 0,785081 \\
Administração & 0,779330 \\
Química & 0,772586 \\
Música & 0,760185 \\
Teatro & 0,759560 \\
Biologia & 0,741856 \\
Geografia & 0,715597 \\
História & 0,710779 \\
Filosofia & 0,600646 \\
\hline MÉDIA & $\mathbf{0 , 8 3 1 3 5 8}$ \\
\hline Fonte: IPEA (2006) & \\
\hline
\end{tabular}

\subsection{Eficiência de Escala}

A Tabela 16 a seguir demonstra o Indicador de Eficiência de Escala e o seu respectivo ranking. Verificamos que os curso de Enfermagem e Serviço Social estão na "escala ótima", pois atingiram o escore $=1$, relativa a eficiência de escala, ou seja, produzem o máximo de produtos com a utilização mínima de insumos. Esses cursos também estão sobre a fronteira de eficiência técnica nas posições $2^{\circ}$ e $3^{\circ}$ do ranking, conforme Tabela 7. Entretanto, o curso de Relações Internacionais não atingiu o escore 1 na eficiência de escala e mesmo estando sobre a fronteira de eficiência técnica possui um escore 0,20 na eficiência de escala. 
Tabela 16 - Ranking de Eficiência de Escala

\begin{tabular}{|c|c|c|}
\hline Cursos Avaliados & Ranking Eficiência de escala & Eficiência de escala \\
\hline Enfermagem & 1 & 1000000 \\
\hline Serviço Social & 1 & 1000000 \\
\hline Agronomia & 3 & 0.372516 \\
\hline Geografia & 4 & 0.331152 \\
\hline Farmácia & 5 & 0.322805 \\
\hline Odontologia & 6 & 0.318360 \\
\hline Filosofia & 7 & 0.308246 \\
\hline Publicidade e Propaganda & 8 & 0.305153 \\
\hline Física & 9 & 0.303941 \\
\hline Música & 10 & 0.303376 \\
\hline Arquivologia & 11 & 0.301668 \\
\hline Teatro & 12 & 0.295644 \\
\hline Matemática & 13 & 0.294815 \\
\hline Estatística & 14 & 0.291402 \\
\hline Jornalismo & 15 & 0.286318 \\
\hline $\begin{array}{l}\text { Bacharelado Ciência da } \\
\text { Computação }\end{array}$ & 16 & 0.271563 \\
\hline Medicina & 17 & 0.270858 \\
\hline Nutrição & 18 & 0.261099 \\
\hline Engenharia Civil & 19 & 0.259159 \\
\hline Química & 20 & 0.246388 \\
\hline História & 21 & 0.242348 \\
\hline Biologia & 22 & 0.225614 \\
\hline Ciências contábeis & 23 & 0.222404 \\
\hline Administração & 24 & 0.219375 \\
\hline Direito & 25 & 0.212182 \\
\hline Design & 26 & 0.204495 \\
\hline Relações Internacionais & 27 & 0.197286 \\
\hline
\end{tabular}

Fonte: Elaboração própria

Sabe-se que o modelo VRS permite lidar com eficiências de escala, ou seja, um curso eficiente não precisa ter a máxima relação entre outputs $e$ inputs, uma vez que se considera a escala de operação. Essa característica permite, por exemplo, que firmas de tamanhos diferentes (grande porte, médio e pequeno porte) sejam analisadas utilizando o mesmo modelo. A estrutura matemática dos modelos do DEA faz com que uma DMU seja considerada eficiente por serem atribuídos pesos nulos a algumas variáveis. Tais variáveis são desconsideradas na avaliação da eficiência daquela unidade, podendo acarretar uma avaliação incompleta. Torna-se possível complementar o modelo matemático adicionando restrições que permitem variar os pesos em certas faixas pré-definidas, minimizando a quantidade de variáveis que recebem peso zero, conforme (ALLEN et. al. 1997 apud MELLO et al. 2003). 
Este modelo permite captar os efeitos ao longo da função de produção decorrentes de alterações na escala de produção, uma vez que considera os retornos constantes à escala.

Ora percebemos que o curso de Relações Internacionais, ficou com coeficiente de escala de 0,20, ou seja, para esse curso alcançar a eficiência de escala deve diminuir a ineficiência em 0,80 . Essa lógica poderá ser aplicada a todos os cursos que apresentaram escores baixo de 1.

Cabe destacar que o valor máximo de Eficiência de Escala (EE) é 1, indicando que a DMU está operando no tamanho de escala mais produtivo. Ora, a EE pode ser utilizada para determinar o quão próximo cada um dos cursos da amostra está de seu correspondente tamanho de escala mais produtivo, e quanto isso é reflexo de seus esforços. Entendemos que os resultados da eficiência de escala podem indicar às DMUs oportunidades para reflexão, ou seja, reestruturação organizacional, racionalização dos processos ou consolidação de operações que por ventura estão dando certo. A ideia é verificar, por meio da eficiência de escala, uma alocação mais racional de recursos (inputs) à demanda (outputs).

\subsection{Eficiência Técnica e de Escala}

Após falarmos um pouco de cada uma dessas medidas de eficiência produzidas pelo DEA, trazemos a Tabela 17 comparando os escores de Eficiência Técnica e de Escala. Sabemos que os 8 (oito) primeiros cursos listados à esquerda na Tabela 17 obtiveram escore=1, ou seja, possuem Eficiência Técnica (ET), quais sejam: Relações Internacionais; Serviço Social; Enfermagem; Agronomia; Farmácia; Medicina; Odontologia e Design. Desses cursos, os de Enfermagem e Serviço Social também apresentaram escore=1 na Eficiência de Escala (EE).

Os cursos de Agronomia, Farmácia e Odontologia, apesar de não apresentarem escore $=1$ na eficiência de escala, estão entre os primeiros do ranking, o que se assemelha com ranking de Eficiência Técnica. Sabemos que não necessariamente esse ranking vai coincidir, pois como vimos, foram análises sob as óticas e modelos diferentes. Todavia, o que mais nos chama a atenção é que o curso de Relações Internacionais mesmo sendo o mais eficiente tecnicamente foi o último no ranking da eficiência por escala. Cabe destacar que o curso de Relações Internacionais possui duas variáveis (inputs) com valores máximos no ranking, quais sejam: a nota (média) de formação geral de alunos ingressantes e o salário médio de docentes DE, já sua RAP é baixa. Tais indicadores favoreceram o curso para atingir a 
fronteira de Eficiência Técnica, em contrapartida, na eficiência de escala o mesmo curso está distante da fronteira tal fato ocorre devido a análise distintas (retornos constantes e retornos variáveis). Alguns cursos estão em posições bem próximas tanto na ET como na EE, tais como: Matemática; Estatística; Química; Biologia. Já o curso de Filosofia, o último no ranking de ET está na $7^{\mathrm{a}}$ posição do ranking da EE.

Tabela 17 - Comparação Ranking de Eficiência Técnica e de Escala

\begin{tabular}{|c|c|c|c|}
\hline Cursos Avaliados & $\begin{array}{c}\text { Ranking } \\
\text { Eficiência Técnica }\end{array}$ & Cursos Avaliados & $\begin{array}{c}\text { Ranking } \\
\text { Eficiência de escala }\end{array}$ \\
\hline Relações Internacionais & 1 & Enfermagem & 1 \\
\hline Serviço Social & 1 & Serviço Social & 1 \\
\hline Enfermagem & 3 & Agronomia & 3 \\
\hline Agronomia & 4 & Geografia & 4 \\
\hline Farmácia & 5 & Farmácia & 5 \\
\hline Medicina & 6 & Odontologia & 6 \\
\hline Odontologia & 7 & Filosofia & 7 \\
\hline Design & 8 & Publ. e Propaganda & 8 \\
\hline Arquivologia & 9 & Física & 9 \\
\hline Direito & 10 & Música & 10 \\
\hline Engenharia Civil & 11 & Arquivologia & 11 \\
\hline Nutrição & 12 & Teatro & 12 \\
\hline Matemática & 13 & Matemática & 13 \\
\hline Ciências contábeis & 14 & Estatística & 14 \\
\hline Estatística & 15 & Jornalismo & 15 \\
\hline Física & 16 & $\begin{array}{l}\text { Bach. Ciência da } \\
\text { Computação }\end{array}$ & 16 \\
\hline Publicidade e Propaganda & 17 & Medicina & 17 \\
\hline $\begin{array}{l}\text { Bacharelado Ciência da } \\
\text { Computação }\end{array}$ & 18 & Nutrição & 18 \\
\hline Jornalismo & 19 & Engenharia Civil & 19 \\
\hline Administração & 20 & Química & 20 \\
\hline Química & 21 & História & 21 \\
\hline Música & 22 & Biologia & 22 \\
\hline Teatro & 23 & Ciências contábeis & 23 \\
\hline Biologia & 24 & Administração & 24 \\
\hline Geografia & 25 & Direito & 25 \\
\hline História & 26 & Design & 26 \\
\hline Filosofia & 27 & Rel. Internacionais & 27 \\
\hline
\end{tabular}

Fonte: Elaboração própria 
A necessidade de investimento na provisão da educação é explicada em termos de eficiência econômica, e nas externalidades positivas diretamente relacionadas à sociedade que são produzidas pela educação. Assim, como vimos no decorrer deste estudo, a educação contribui para melhores noções de cidadania, redução da violência, propicia qualidade de vida e melhora a produtividade no mercado de trabalho. Sendo, sem dúvida, o principal instrumento gerador de capital humano. Ora, ressalta-se que investimentos eficientes na educação propiciam crescimento e desenvolvimento econômico para o país.

Sendo assim, espera-se que este trabalho contribua para uma reflexão dos gestores da Universidade de Brasília no que tange a melhor qualidade na aplicação de recursos públicos. Esse tipo de reflexão é importante, pois a partir da construção de fronteiras de eficiência, verifica-se a existência de situações que podem ser melhoradas, possibilitando uma melhoria no desempenho dos cursos ineficientes tecnicamente sem que necessitem aumentar os recursos investidos, mas somente utilize-os de forma mais eficiente.

Vimos que o DEA possibilitou a mensuração do desempenho das DMUs através de comparações de seus resultados, e com base neste método, pode-se avaliar a eficiência dos gastos com os cursos de graduação da UnB, para os anos de 2008, 2009 e 2010. O estudo demonstrou que menos de $30 \%$ do total dos cursos (DMUs) avaliados na nossa amostra são eficientes tecnicamente, quais sejam: Relações Internacionais; Serviço Social; Enfermagem; Agronomia; Farmácia; Medicina; Odontologia e Design. Contudo, mesmo com percentual alto, ou seja mais de $70 \%$, os cursos ineficientes tecnicamente apresentaram escores 0,96 a 0,60, considerado ineficiência fraca e moderada. Isso significa que, se os gestores se empenharem na melhoria da aplicação dos recursos, muito provavelmente, pode haver uma mudança positiva no cenário atual. Quanto a eficiência de escala, apenas dois cursos obtiveram escore igual a 1, quais sejam: os cursos de Enfermagem e Serviço Social. Tanto na eficiência técnica quanto na eficiência de escala a maioria dos cursos (DMUs) avaliados neste estudo demonstraram índices de ineficiência.

Cumpre destacar que esse resultado poderia ser diferenciado dependendo das variáveis utilizadas no estudo (inputs e outputs). Além disso, sabemos que no período desta análise (2008 a 2010) a Universidade estava em plena adaptação devido ao Programa REUNI, quando o número de cursos ofertados pela Universidade de Brasília deu um salto. Nos anos de 2004 a 2007 a média de cursos ofertados era de 64, enquanto que nos anos de 2008 a 2012, 
ano do Reuni, esse número de cursos de um salto sendo uma média de 110, ou seja, quase $72 \%$ a mais na oferta de cursos. Sabe-se que as Universidades tiveram que se adaptar ao REUNI ao mesmo tempo que se aumentava o número de alunos e cursos, o que não ocorreu na mesma proporção a construção de salas, aquisição de equipamentos e contratação de servidores, esse fato prejudicou o aprendizado dos alunos, e seu desempenho nas notas do Enade. Assim, o impacto do REUNI afetou a eficiência das IFES, conforme estudos de Oliveira et al. (2015). O que pode ter tornado o número de cursos (DMUs) com essa taxa de $70 \%$ de ineficiência.

Sabe-se que os recursos são escassos, assim a tendência é que se busquem alternativas e ferramentas para utilizá-los com maior eficiência possível. Entende-se que a busca por recursos próprios poderia alavancar os investimentos com a educação na Universidade de Brasília, e consequentemente produzir melhores resultados na formação de seus alunos.

Cabe destacar que a Universidade dispõe de autonomia universitária, conforme artigo 207 da Constituição Federal de 1988, o que a credencia para a captação de recursos próprios como uma alternativa de sobrevivência da própria Instituição, considerando a continuada redução de verbas disponibilizadas pelo Estado. Estudos diversos demonstram vários fatores internos que tem concorrido para ampliação da geração de recursos próprios na Universidade de Brasília, quais sejam: administração mais eficiente; redução dos gastos com pagamentos de dívidas mantidas com bancos; ampliação do número de parcerias; dentre outros benefícios.

Assim sendo, entende-se que esses recursos poderão ser aplicados para melhorias diversas na Universidade, como por exemplo, na aquisição de equipamentos modernos para uso nos laboratórios; contratação de especialistas para ministrar seminários, a fim de fomentar a inovação tecnológica entre os alunos e a sociedade à sua volta; reforma de salas, auditórios, entre outras ações que certamente trariam, em curto espaço de tempo, retornos positivos à toda comunidade universitária e à sociedade. 


\section{REFERÊNCIAS}

AMARANTE, P. A.; MOREIRA, I. T. A evolução dos Gastos Públicos por função e por grupo de despesas no período de 1980-2006. ENCONTRO DE INICIAÇÃO A DOCÊNCIA, 11., 2009, João Pessoa. João Pessoa: UPF, 2009. Disponível em: $<$ http://www.prac.ufpb.br/anais/xenex_xienid/xi_enid/monitoriapet/ANAIS/Area8/8CCSADE MT05-P.pdf>

AMERICANO DA COSTA, N. M. A. da. Reflexões e propostas: universidade com autonomia. Proposta elaborada para a postulação ao cargo de Reitora da UFBA. Salvador, 2002. Não publicado.

ARAÚJO, J. A.; MONTEIRO, V. B.; CAVALCANTE, C. A. A influência dos gastos públicos no crescimento econômico dos municípios do Ceará. In: Carvalho, E. B. S (Org.) ENCONTRO DE ECONOMIA DO CEARÁ EM DEBATE, 6., 2010. Fortaleza: IPECE, $2010 . \quad$ Disponível em: $\langle$ http://www.repositorio.ufc.br/ri/bitstream/riufc/5428/1/2010_capliv_jaaraujo.pdf $>$. Acesso em: 10 mai $>2015$.

ATAÍDE, M. A. A Universidade do futuro diante das transformações globais: que futuro espera-se. Revista Multidisciplinar Acadêmica Vozes dos Vales - UFVJM, Minas Gerais, ano III, n. 5, p. 1-24, mai. 2014. Disponível em: $<$ http://site.ufvjm.edu.br/revistamultidisciplinar/files/2014/05/A-Universidade-do-futurodiante-das-transforma\%C3\%A7\%C3\%B5es-globais.pdf>. Acesso em: 10 dez. 2014.

BANCO CENTRAL DO BRASIL (BCB). Relatório de Inflação, vol. 17, n. 2, jun. 2015. Disponível em: <http://www.bcb.gov.br/htms/relinf/port/2015/06/ri201506P.pdf>. Acesso em: 12 ago. 2015.

BANKER, R. D. Maximum likelihood, consistency and data envelopment analysis: a statistical foundation. Management Science, Minneapólis, v. 39, n. 10, p. 1265-1273, 1993. Disponível em: 〈http://pubsonline.informs.org/doi/abs/10.1287/mnsc.39.10.1265〉. Acesso em: 1 fev> 2015.

BANKER, R. D; CHARNES, A.; COOPER, W. W. Some models for estimating technical and scale inefficiencies in data envelopment analysis. Management Science, v. 30, n. 9, p. 1078-1092, 1984.

BARROS, R. P. de; HENRIQUES, R.; MENDONÇA, R. Pelo fim das décadas perdidas: Educação e Desenvolvimento Sustentado no Brasil. Rio de Janeiro: IPEA, jan./2002. Texto para Discussão 857.

BARROS, R. P. de; MENDONÇA, R. Investimentos em educação e desenvolvimento econômico. Rio de Janeiro: IPEA, nov./1997. Texto para Discussão 525. Disponível em: $\langle$ http://www.ipea.gov.br/portal/index.php?option=com_content\&view=article \&id=3772>.

Acesso em: 10 fev. 2015.

BELLONI, J. A. Uma metodologia de avaliação da eficiência produtiva da Universidades Federais Brasileiras. 2000. 245 f. Tese (Doutorado em Engenharia de Produção) - 
Departamento de Engenharia de Produção e Sistemas, Universidade Federal de Santa Catarina, Florianópolis.

BERTÊ, A. M. DE A.; BORGES, C. B.; BRUNET, J. F. G. Qualidade do Gasto Público em educação nas Redes Públicas Estaduais e Municipais. In: CONGRESSO CONSAD DE GESTÃO PÚBLICA, 2, 2009, Brasília. Brasília: CONSAD, 2009. Disponível em: <http://repositorio.fjp.mg.gov.br/consad/bitstream/123456789/422/1/C2_TP_QUALIDADE\% 20DO\%20GASTO\%20P\%C3\%9ABLICO\%20EM\%20EDUCA\%C3\%87\%C3\%830.pdf>.

Acesso em: 10 mai. 2015.

BIONDI NETO, L. N. Neuro-DEA: Nova metodologia para determinação de eficiência relativa de Unidades Tomadoras de Decisão. Engenharia de Produção, Rio de Janeiro, vol. $500,2001$.

BORGES, D. P. A expansão do ensino superior público no Brasil e a questão do financiamento no período 1995-2002: o caso da Universidade de Brasília. Sociedade e Estado, Brasília, v. 20, n. 3, p. 741-744, set./dez. 2005. Disponível em: <http://www.scielo.br/pdf/se/v20n3/v20n3a12.pdf $>$. Acesso em: 21 mai. 2015.

BOUERI, R. Modelos não paramétricos: Análise Envoltória de Dados (DEA). In: BOUERI, R.; ROCHA, F.; RODOPOUlOS, F. (Orgs.). Avaliação da Qualidade do Gasto Público e Mensuração da Eficiência. Brasília: Secretaria do Tesouro Nacional, 2015. Capítulo 8, p. 269-305. Disponível em: <https://www.tesouro.fazenda.gov.br/documents/10180/318974/COR_LIVRO_Avaliacao_da _Qualidade_do_Gasto_Publico_e_Mensuracao_de_Eficienc.../1e3a7622-3628-4e35-b622eb3c53b20fc4>. Acesso em: 08 jul. 2015.

BRASIL. Constituição da República Federativa do Brasil de 1988. Disponível em: <http://www.planalto.gov.br/ccivil_03/constituicao/constituicao.htm>. Acesso em: 19 mai. 2015.

BRASIL. Estatuto da Criança e do Adolescente. Lei n. 8.069, de 13 de julho de 1990. Dispões sobre a proteção integral à criança e ao adolescente. Diário Oficial \{da\} República Federativa do Brasil. Brasília, DF, 13 jul. 1990. Disponível em: <http://www.planalto.gov.br/ccivil_03/leis/18069.htm>. Acesso em: 19 mai. 2015.

BRASIL. Lei de Diretrizes e Base da Educação Nacional. Lei n. 9.394, de 20 de dezembro de 1996. Estabelece as diretrizes e bases da educação nacional. Diário Oficial \{da\} República Federativa do Brasil. Brasília, DF, 20 dez. 1996. Disponível em: <http://www.planalto.gov.br/ccivil_03/leis/19394.htm>. Acesso em: 19 mai. 2015.

BRASIL. Decreto 6.096, de 24 de abril de 2007. Institui o Programa de Apoio ao Plano de Reestruturação e Expansão das Universidades Federais (REUNI). Diário Oficial \{da\} República Federativa do Brasil. Brasília, DF, 24 abr. 2007. Disponível em: <http://www.planalto.gov.br>. Acesso em: 19 mai. 2015.

BUCHANAN, J. Rent Seeking and Profit Seeking. In: BUCHANAN, J.; TOLLISON R.; G. TULLOCK. Toward a Theory of the Rent Seeking Society. College Station, TX: Texas A\&M University Press, 1990. 
CÂNDIDO JUNIOR, J. O. Os gastos públicos no Brasil são produtivos? Planejamento de Políticas Públicas, Rio de Janeiro, n. 23, p. 233-260, jun. 2001. Disponível em: <http://www.ipea.gov.br/ppp/index.php/PPP/article/view/77> Acesso em: 20 mai. 2015.

CASADO, F. L.; SOUZA, A. M. Análise Envoltória de Dados: Conceitos, Metodologia e Estudo da Arte na Educação Superior. Revista do Centro de Ciências Sociais e Humanas da UFSM (Cessou em 1983), Santa Maria, v. 1, p. 1-154, 2007.

CASTRO, C. de M. A penosa evolução do ensino. In: Pisa 2000 - Relatório Nacional. Brasília: OECD, 2001. P. 1-88. Disponível em: <http://www.oecd.org/edu/school/programmeforinternationalstudentassessmentpisa/33683964 .pdf>. Acesso em: 10 mar. 2015.

CASTRO, J. A. de; DUARTE, B. DE C. Descentralização da educação pública no Brasil: Trajetória dos gastos e das matrículas. Brasília: IPEA: ago./2008. Texto para discussão 1352. Disponível em: <http://repositorio.ipea.gov.br/bitstream/11058/1530/1/TD_1352.pdf $>$. Acesso em: 19 mai. 2015.

CASTRO, J. A. de; SADECK, F. Financiamento do gasto em educação das três esferas do governo em 2000. Brasília: IPEA, jun./2003. Texto para discussão 955. Disponível em: $\langle$ http://repositorio.ipea.gov.br/bitstream/11058/2887/1/TD_955.pdf >. Acesso em: 19 mai. 2015.

CASTRO, M. H. de M.; LEITE, E. M. Educação no Brasil: atrasos, conquistas e desafios. In: TAFNER, P (Org.). Brasil: o estado de uma nação - mercado de trabalho, emprego e informalidade. Rio de Janeiro: IPEA, 2006. Cap. 3, p. 121-228. Disponível em: 〈http://www.ipea.gov.br/portal/images/stories/PDFs/livros/livro_brasil_desenv_en_2006.pdf $>$ . Acesso em: 19 mai. 2015.

CHARNES, A.; COOPER, W. W.; RHODES, E. Measuring the efficiency of decision making units. European Journal of Operational Research, Cambridge, v. 2, n. 6, p. 429444, 1978. Disponível em: 〈http://www.utdallas.edu/ ryoung/phdseminar/CCR1978.pdf>. Acesso em: 2 fev. 2015.

COELLI, T. J. Recent developments in frontier modelling and efficiency measurement. Australian Journal of Agricultural Economics, v. 39, n. 3, p. 219-245, 1995. Disponível em: <http://ageconsearch.umn.edu/bitstream/22681/1/39030219.pdf >. Acesso em: 30 mar. 2015.

CORBUCCI, P. R. As Universidades Federais: gastos, desempenho, eficiência e produtividade. Brasília: IPEA, ago./2000. Texto para discussão 752.

CORBUCCI, P. R.; MARQUES, P. M. F. Fontes de Financiamento das Instituições Federais de Ensino Superior: Um estudo sobre a Universidade de Brasília. Brasília: IPEA: nov./2003. Texto para discussão 999.

COSMOS, G. J. Economias de Aglomeração, tamanho de cidades e qualidade da Universidade. 2013. 99 f. Dissertação (Mestrado em Gestão Econômica de Finanças Públicas) - Faculdade de Administração, Contabilidade e Economia, Programa de Pós- 
Graduação em Economia, Universidade de Brasília, Brasília. Disponível em: $\langle$ http://repositorio.unb.br/bitstream/10482/14521/1/2013_\%20GilvamJoaquimCosmo.pdf>.

Acesso em: 10 dez. 2014.

COSTA, E. M.; RAMOS, F. de S.; SOUZA, H. R. Mensuração de Eficiência Produtiva das Instituições Federais de Ensino Superior (Ifes). Brasília: ESAF, 2010. Monografia premiada com o $2^{\circ}$ lugar no XV Prêmio Tesouro Nacional - 2010. Disponível em: $<$ http://www3.tesouro.fazenda.gov.br/Premio_TN/XVPremio/qualidade/2qualidadeXVPTN/T ema_2_2.pdf>. Acesso em: 10 mai. 2015.

CRUZ, B.; TEIXEIRA, J. The Impact of Public Investment on Private Investment in Brazil 1947-1990. CEPAL Review, Santiago, v. 67, p. 75-84, apr. 1999.

CUBBIN, J.; TZANIDAKIS, G. Regression versus DEA for efficiency measurement: an application to the England and wales regulated water industry. Utilities Policy, London, v. 7, p. 75-85, 1998.

DEBREU, G. The coefficient of resource utilization. Econometrica, New York, v. 19, n. 3, p. 273-292, 1951.

DELGADO, V. M. S.; MACHADO, A. F. Eficiência das escolas públicas estaduais de Minas Gerais. Pesquisa e Planejamento Econômico, Rio de Janeiro, v. 37, n. 3, dez. 2007.

DEPRINS, D.; SIMAR, L.; TULKENS, H. Measuring Labor Inefficiency in Post Offices. In: MARCHAND, M.; PESTIEAU, P.; TULKENS, H. (Ed.). The Performance of Public Enterprises: Concepts and Measurements. Amsterdam: North-Holland, 1984. P. 243-267.

DUARTE, J. et al. Federalismo e Descentralização. In: BOUERI, R.; ROCHA, F.; RODOPOUlOS, F. (Orgs.). Avaliação da Qualidade do Gasto Público e Mensuração da Eficiência. Brasília: Secretaria do Tesouro Nacional, 2015. Capítulo 11, p. 377-391. Disponível em: <https://www.tesouro.fazenda.gov.br/documents/10180/318974/COR_LIVRO_Avaliacao_da _Qualidade_do_Gasto_Publico_e_Mensuracao_de_Eficienc.../1e3a7622-3628-4e35-b622eb3c53b20fc4>. Acesso em: 08 jul. 2015.

ESTACHE, A.; MARTIN, A.R. How different is the efficiency of public and private water companies in Asia? The World Bank Economic Review, v. 16, n. 1, p. 139-148, jan. 2002.

FÄRE, R.; GROSSKOPF, S.; LOVELL, C. A. K. Production frontiers. New York: Cambridge University, mai./1995.

FARREL, M. J. The measurement of Productive Efficiency. Journal of the Royal Statistical Society, series A, n. 120, v. 3, p. 253-290, 1957. Disponível em: <http://www.aae.wisc.edu/aae741/Ref/Farrell\%201957.pdf>. Acesso em: 20 jan. 2015.

FERREIRA, P. C. Investimento em infraestrutura no Brasil: fatos estilizados e relações de longo prazo. Pesquisa e Planejamento Econômico, Rio de Janeiro, v. 26, n. 2, p. 231-252, 1996. 
FERREIRA, P.; MALLIAGROS, T. Impactos Produtivos da Infra-Estrutura no Brasil 1950/95. Pesquisa e Planejamento Econômico, Rio de Janeiro, v. 28, n. 2, p. 315-338, ago. 1998.

FERREIRA, M. A. M.; BRAGA, M. J. Eficiência Técnica e de Escala de Cooperativas e Sociedades de Capital na Indústria de Laticínios do Brasil. In: ENCONTRO NACIONAL DE ECONOMIA, 33, Natal, 2005. Natal: ANPEC, 2005. Disponível em: <http://www.anpec.org.br/encontro2005/artigos/A05A144.pdf $>$. Acesso em: 28 jun. 2015.

FIGUEIRAS, L. Faculdade e indústria, parceria possível e necessária. Gazeta Mercantil, Vitória, 10 jun. 1998, p. 2.

FRANCO, F.; FORTUNA, M. O método de fronteira estocástica na medição da eficiência dos serviços hospitalares: Uma revisão bibliográfica. Associação Portuguesa de Economia da

Saúde, cidade, $\quad$ n. $2, \quad$ fev. 2013. 2 Disponível em: $<$ http://www.academia.edu/7556961/O_M\%C3\%89TODO_DE_FRONTEIRA_ESTOC\%C3 \%81STICA_NA_MEDI\%C3\%87\%C3\%830_DA_EFICI\%C3\%8ANCIA_DOS_SERVI\%C3 $\% 870 S$ HOSPITALARES_UMA_REVIS\%C3\%830_BIBLIOGR\%C3\%81FICA>. Acesso em: 6 mai. 2015.

FRIGOTTO, G. A produtividade da escola improdutiva. 6. Ed. São Paulo: Cortez, 2001.

GOMES, E. G. et al. Avaliação de eficiência de companhias aéreas brasileiras: uma abordagem por Análise de Envoltória de Dados. In: SETTI, J. R. A.; LIMA JUNIOR O.F. (Eds.). Panorama Nacional da Pesquisa em Transportes. Anais do XV ANPET, Campinas, v. 2, p. 125-133, nov. 2001.

GONÇALVES, E. de A. Gastos Públicos com Educação Superior: Evolução dos Gastos Federais com a Universidade de Brasília entre 2003 a 2010. 2013. X f. Dissertação (Mestrado Profissional em Economia) - Faculdade de Administração, Contabilidade e Economia, Programa de Pós-Graduação em Economia, Universidade de Brasília, Brasília.

GUIMARÃES, J. F.; SAMPAIO, B. The influence of Family background and individual characteristics on entrance tests scores of Brazilian university students. In: ENCONTRO NACIONAL DE ECONOMIA, 35., Recife, 2007. Recife: ANPEC, 2007. Disponível em: 〈http://www.anpec.org.br/encontro2007/artigos/A07A092.pdf>. Acesso em: 10 jan. 2015.

HAGEN, E. E. Economia do desenvolvimento. Tradução de Auriphebo Berrance Simões. São Paulo: Atlas, 1971.

HANNUM, E., BUCHMANN, C. The consequences of global educational expansion. Cambridge, MA: American Academy of Arts and Sciences, 2003.

HANUSHEK, E.; RAYMOND, M. The effect of School Accountability Systems on the Level and Distribution of Student Achievement. Journal of the Europen Economic Association, Standford, n. 2, p. 406-415, 2004.

HIRSCHMAN, A. O. Exit, voice, and loyalty; responses to decline in firms, organizations, and states. Cambridge, MA: Harvard University Press, 1970. 
INSTITUTO NACIONAL DE ESTUDOS E PESQUISAS EDUCACIONAIS ANÍSIO TEIXEIRA (INEP). Portal Institucional do INEP. Disponível em: <http://portal.inep.gov.br/>. Acesso em: 03 jan. 2015.

INSTITUTO DE PESQUISA ECONÔMICA APLICADA (IPEA). Boletim de Desenvolvimento Fiscal, n. 3, p. 5-63, dez. 2006. Disponível em: 〈http://www.ipea.gov.br/agencia/images/stories/PDFs/Boletim_desenv_fiscal/bdf_03.pdf $>$.

Acesso em: 12 abr. 2015.

KUMBHAKAR, S.; LOVELL, K. Sthocastic frontier analysis. Cambridge: Cambridge University Press, 2000.

LINS, M. P. E; MEZA, A. L. Análise Envoltória de Dados e Perpectivas de Integração no Ambiente de Apoio à Decisão. Rio de Janeiro: Editora da COPPE/UFRJ, 2000.

LOVELL, C. A. K.; SCHMIDT, S. S. (Eds.). The measurement of productive efficiency. New York: Oxford University, 1993.

MARTINS, A. C. P. Ensino Superior no Brasil: da descoberta aos dias atuais. Acta Cirúrgica Brasileira, São Paulo, vol.17, p. 4-6, 2002. Suplemento 3. Disponível em: <http://www.scielo.br/pdf/acb/v17s3/15255.pdf >. Acesso em: 12 jan. 2015

MATTOS, E.; TERRA, R. Conceitos sobre eficiência. In: BOUERI, R.; ROCHA, F.; RODOPOULOS, F. (Orgs.). Avaliação da Qualidade do Gasto Público e Mensuração da Eficiência. Brasília: Secretaria do Tesouro Nacional, 2015. Capítulo 7, p. 235-265. Disponível em: $<$ https://www.tesouro.fazenda.gov.br/documents/10180/318974/COR_LIVRO_Avaliacao_da _Qualidade_do_Gasto_Publico_e_Mensuracao_de_Eficienc.../1e3a7622-3628-4e35-b622eb3c53b20fc4>. Acesso em: 08 jul. 2015.

MAZONI, M. G. Gastos públicos e crescimento econômico no Brasil: análise dos impactos dos gastos com custeio e investimento. 2005. Dissertação (Mestrado) - Faculdade de Economia, Administração e Contabilidade, Universidade de São Paulo São Paulo.

MELLO, J. C. C. B. S. et al. Análise de Envoltória de Dados no Estudo da Eficiência e dos Benchmarks para Companhias Aéreas Brasileiras. Pesquisa Operacional, Rio de Janeiro, v. 23, n. 2, p. 325-345, mai./ago. 2003.

MENDES, M. Eficiência do Gasto Público: o governo focado na solução das "falhas de mercado". In: Ciclo de Palestras para Gestores Públicos da Escola de Governo do Instituto de Desenvolvimento Sustentável e Meio Ambiente. Rio Grande do Norte: IDEMA, 2008.

MENEZES, R. M. Processos de Gasto e Descentralização na Política Educacional Brasileira. Aberto, v. 18, n. 74, p. 58-71, dez. 2001.

MOREIRA, A. R. B.; FONSECA, T.C.R. Comparando medidas de produtividade: DEA, Fronteira de Produção Estocástica. Rio de Janeiro: IPEA, fev./2005. Texto para Discussão 1069. Disponível em: 〈http://repositorio.ipea.gov.br/bitstream/11058/1985/1/TD_1069.pdf〉. Acesso em: 19 mai. 2015. 
NEGRI, J. A. DE. Desempenho Exportador das Firmas Industriais no Brasil: A influência da Eficiência de Escala e dos Rendimentos Crescentes de Escala. Brasília: IPEA, nov./ 2003. Texto para Discussão 997.

NEGRI, J. A. FREITAS, F. Inovação Tecnológica, Eficiência de Escala e Exportações Brasileiras. Brasília: IPEA, set./2004. Texto para Discussão 1044.

NEVES, C. E. B. Ensino Superior no Brasil: Expansão, Diversificação e Inclusão. In: CONGRESSO INTERNACIONAL DA ASSOCIAÇÃO DE ESTUDOS LATINO AMERICANO, 30., San Francisco, 2012. San Francisco: LASA, 2012. Disponível em: <http://www.ufrgs.br/geu/Artigos\%202012/Clarissa\%20Baeta\%20Neves.pdf $>$. Acesso em: 3 jan. 2015.

OHIRA, T. H.; SHIROTA, R. Eficiência Econômica: uma aplicação do modelo de Fronteira Estocástica em empresas de saneamento. In: ENCONTRO NACIONAL DE ECONOMIA, 33., 2005. Natal: ANPEC, 2005. Disponível em: <http://www.anpec.org.br/encontro2005/artigos/A05A142.pdf $>$. Acesso em: 20 fev. 2014.

OLIVEIRA, A. J. et al. Programa Reuni nas Instituições de Ensino Superior Federal (IFES) brasileiras: Um estudo da eficiência operacional por meio da Análise Envoltória de Dados (DEA) no período de 2006 a 2012. Race, Joaçaba, v. 13, n. 3, p. 1179-1210, set./dez. 2015.

OLIVEIRA, H. C. Gastos Públicos Federais $\mathbf{x}$ Ensino Superior $\mathbf{x}$ Expansão da Universidade de Brasília. 2003. 68 f. Dissertação (Mestrado em Economia) - Faculdade de Administração, Contabilidade e Economia, Programa de Pós-Graduação em Economia, Universidade de Brasília, Brasília.

PENÃ, C. R. Um Modelo de Avaliação da Eficiência da Administração Pública através do Método Análise Envoltória de Dados (DEA). RAC, Curitiba, v. 12, n. 1, p. 83-106, jan./mar. 2008. Disponível em: 〈http://www.scielo.br/pdf/rac/v12n1/a05v12n1.pdf $>$. Acesso em: 21 jun. 2015.

PEREIRA, M. C.; MOREIRA, S. A Stochastic frontier analysis of secondary education output in Portugal. Banco de Portugal, 2007. Working Paper 6/2007.

RAY, S. Resource-use efficiency in public schools: A study of connecticut data. Management Science, Catansville, n. 37, p. 1620-1628, 1991.

SANTOS, B. S. Pela mão de Alice: o social e o político na pós-modernidade. 4. Ed. São Paulo: Cortez, 1997.

SARAIVA, A.; KLEIN, C. PIB do Brasil contrai-se 0,2\% no primeiro trimestre de 2015. Valor Econômico, São Paulo, 29 mai. 2015. Disponível em: <http://www.valor.com.br/brasil/4072946/pib-do-brasil-contrai-se-02-no-primeiro-trimestrede-2015>. Acesso em: 29 mai. 2015.

SENGUPTA, J. K. A dynamic efficiency model using data envelopment analysis. International Journal of Production Economics, North-Holland, v. 62, p. 209-218, 1999. 
SILVA, F. DE S. N. da. Análise crítica quanto efetivação do direito fundamental à educação no Brasil como instrumento de transformação social. Revista dos Advogados de São Paulo. São Paulo: Revista dos Tribunais, jun. 2008. Disponível em: $\langle$ http://ww3.lfg.com.br/public html/article.php?story=20080624114112546\&mode=print $>$.

Acesso em: 1 jun. 2014.

SISTEMA INTEGRADO DE ADMINISTRAÇÃO DE RECURSOS HUMANOS (SIAPE): sítio oficial das informações do Sistema Integrado de Administração de Recursos Humanos elaborado pela Secretaria de Gestão Pública do Ministério do Planejamento, Orçamento e Gestão. Disponível em: 〈http://www.siapenet.gov.br/Portal/Servico/Apresentacao.asp $>$. Acesso em: 10 mar. 2015.

SOBRINHO, J. D. Concepções de universidade e de avaliação institucional. In: Trindade, H. Universidade em ruínas - na república de professores. Petrópolis: Vozes, 2001. p.149-169.

TAKAHASHI, F.; TUROLLO JR, R. Crise financeira faz universidades públicas paulistas cortarem gastos. Folha de S.Paulo, São Paulo, 10 abr. 2015. Disponível em $<$ http://www1.folha.uol.com.br/educacao/2015/04/1614733-crise-financeira-fazuniversidades-publicas-paulistas-cortarem-gastos.shtml>. Acesso em: 8 mai. 2015.

TEIXEIRA, C. Fundações: complementação salarial e repasse para as instituições. In: DAL ROSSO, S. (Org.) Fórum em defesa da universidade pública e gratuita. Brasília: ADUNB, 2002.

UNIVERSIDADE DE BRASÍLIA (UNB). Relatório Anuário Estatístico 2014 - (2009-2013). Brasília: Fundação Universidade de Brasília, 2014. Disponível em: <http://www.dpo.unb.br/documentos/anuario/Anuario_2014.pdf >. Acesso em: 2 fev. 2015.

VARIAN, H. R. Microeconomic Analysis. 3. Ed. New York: W.W. Norton \& Co. 1992.

VELLOSO, J. Universidade na América Latina: rumos do financiamento. Cadernos de Pesquisa, São Paulo, n. 110, p. 39-66, 2000. Disponível em: <http://www.scielo.br/pdf/cp/n110/n110a02.pdf >. Acesso em: 21 mai. 2015.

VELLOSO, J.; MARQUES, P. M. F. Recursos Próprios da UnB. O Financiamento das IFES e a Reforma da Educação Superior. Revista Educação e Sociedade, Campinas, v. 26, n. 91, p. 655-680, 2005. Disponível em: 〈http://www.cedes.unicamp.br〉. Acesso em: 3 abr. 2015.

VONBUN, C.; MENDONÇA, J. L. de O. Educação Superior uma comparação internacional e suas lições para o Brasil. Brasília: IPEA, mar./2012. Texto para Discussão n. $1720 . \quad$ Disponível em: 〈http://repositorio.ipea.gov.br/bitstream/11058/1211/1/TD_1720.pdf >. Acesso em: 19 mai. 2015.

WANKE, P. F.; AFFONSO, C. R. Determinantes da Eficiência de Escala no Setor Brasileiro de Operadores Logísticos. Produção, Rio de Janeiro, v. 21, n. 1, p. 53-63, jan./mar. 2011.

WONG, Y.; BEASLEY, J. Restricting weight flexibility in DEA. Journal of Operational Research Society, London, v. 41, p. 829-835, 1990. 
ZANMARIA, N. A.; CASTILHO, M. L. Gastos Públicos com Educação e Seus Reflexos no Crescimento Econômico Brasileiro. Revista Faz Ciência, v. 8, n. 1, p. 123-148, 2006. Disponível em: <http://e-revista.unioeste.br/index.php/fazciencia/article/viewFile/344/258>. Acesso em: 15 mai. 2015.

ZOGHBI, A. C. P. et al. Mensurando o desempenho e a eficiência dos gastos estaduais em educação fundamental e média. Estudos Econômicos, São Paulo, v. 39, n. 4, p-785-809, out./dez. 2009. Disponível em: 〈http://www.scielo.br/pdf/ee/v39n4/04.pdf>. Acesso em: 13 abr. 2015.

ZOGHBI, A.C. P.; ROCHA, F. MATTOS, E. Education production efficiency: Evidence from Brazilian universities. Economic Modelling, v. 31, p. 94-103, nov. 2012. Disponível em: 〈http://www.sciencedirect.com/science/article/pii/S0264999312003744〉. Acesso em: 10 mai. 2015. 